\title{
Explaining Movements in the Labor Share
}

\author{
Samuel Bentolila \\ Gilles Saint-Paul \\ cemf i and cepr Universitat Pompeu Fabra and cepr
}

This version: April 1999

\footnotetext{
${ }^{1}$ We are very grateful to $M$ anuel Arellano for much helpful advice. We wish to thank Brian B ell for supplying us with the CEP-OECD Data Set and Steve Bond for help with DPD98. A preliminary version of this paper was circulated and presented at the MIT International Economics Seminar in M arch 1995, while Saint-Paul was visiting the MIT Economics Department. We are grateful to participants at that workshop and to those at CREST, the M adrid Macroeconomics Workshop (MadM ac), Universitat Pompeu Fabra and Université de Toulouse for their helpful comments.
} 


\begin{abstract}
A bstract
In this paper we study the evolution of the labor share in the OECD since 1970. We show it is essentially related to the capital-output ratio; that this relationship is shifted by factors like the price of imported materials or the skill mix; and that discrepancies between the marginal product of labor and the real wage (due to, e.g., product market power, union bargaining, and labor adjustment costs) cause departures from it. We provide estimates of the model with panel data on 14 industries and 14 countries for 1973-93 and use them to compute the evolution of the wage gap in Germany and the US.

J el cl assification. E25, J 30.

Key words: Labor share, capital-output ratio.
\end{abstract}




\section{Introduction}

In this paper we explore the factors driving the observed movements in the labor share in OECD countries from 1970 to now. The labor share does not very often generate an interest among neoclassical economists, partly because its constancy is taken as a granted "stylized fact of growth". ${ }^{1}$ On the other hand, the labor share is very much present in the political debate as a measure of how the "bene.ts of growth" are shared between labor and capital. For example, its decline since the mid-1980s is often used by unions in Europe as an argument against policies of wage moderation, and by governments in order to justify increased taxation of pro.ts. Moreover, contrary to economists' presumptions, there have been considerable medium-run movements in the labor share over a period of 35 years, as shown in Figures 1 to 4 for several countries. For these reasons, it is important to understand the determinants of the labor share, which is the purpose of this paper.

It is quite striking to ..nd that there are large cross-country dixerences in the behavior of the labor share. The UK exhibits the closest approximation to the "growth stylized fact", with the labor share experiencing large short-run ¥uctuations around a stable level (Figure 1). In the US it undergoes sizable short-run łuctuations around a mild downward trend, becoming essentially $\ddagger$ at in the 1980s (Figure 2). In J apan, on the contrary, it experiences a sharp rise, slowing down considerably after 1975 (F igure 3). T he picture for continental Europe is typically hump-shaped, with the labor share going up and then down. But actual country experiences are heterogeneous: in Germany and France the labor share peaks in the early 1980s (F igure 4), while in other countries like Italy, the Netherlands, and Spain it does so in the mid-1970s.

From a cross-country perspective, it should be noted that these large dixerences across countries take place even though they are relatively similar from a technological point of view. Table 1 shows the evolution of the labor share in the business sector of 14 OECD countries since 1970. As evidenced by its ..rst three columns, the labor share has not converged among these countries during the 1980s (the standard deviation has actually increased). In 1990, some countries like F inland, Sweden or the UK showed labor shares around $72 \%$, while others like France, Germany or Italy had values around $62 \%$.

In the policy debate, movements in the labor share are often interpreted as changes in real wages. It is for example usually heard that because the labor share is currently low in Europe, there is no real wage problem. But this is clearly mistaken, since it all depends on the elasticity of labor demand. The last two columns of Table 1 suggest that the correlation between changes in wages and changes in the labor share is not tight (in other words, labor productivity behaves

\footnotetext{
${ }^{1}$ Recent exceptions are Blanchard $(1997,1998)$ and Caballero and Hammour $(1998)$.
} 
dixerently across countries). For example, from 1970 to 1990 France had one of the sharpest drops in the labor share and an above-average increase in the average real wage, while Sweden had one of the largest increases in the labor share and one of the lowest increases in real wages. ${ }^{2}$ Thus, there is no clear pattern, and a more systematic exploration of the determinants of the labor share is called for.

What can we learn from analyzing the labor share? First of all, it leads to a dixerent approach to the study of labor demand. The traditional analysis of labor demand relates it to factors such as wages, labor-embodied technical progress, and capital (or, alternatively, real interest rates). This type of analysis has often run into trouble, e.g., in estimating the elasticity of labor demand with respect to those factors (see Hamermesh 1993). For some purposes, however, these estimates are not needed, and the labor share provides a compact way of looking at labor demand which directly controls for the role of the above mentioned factors.

We shall show that, as long as labor is paid its marginal product, there should be a one-for-one relationship between the labor share and the capital-output ratio, which we label the share-capital schedule. As long as that condition holds -and it must, at least in long-run equilibrium-, changes in any of those three factors will generate changes of both the labor share and the capital-output ratio along that schedule. A ny change in the labor share which shows up as a deviation from that relationship must arise from a shift in labor demand which is not due to real wages, capital accumulation or technical progress, and therefore has to be explained by other considerations. In what follows, we study the role of factors which displace the schedule, such as changes in the price of imported materials or in the skill mix, and those which put the economy ox the schedule, by changing the gap between the shadow marginal cost of labor and the wage, such as changes in markups of prices over marginal costs, union bargaining power, or labor adjustment costs.

This approach is motivated by an attempt to understand the causes of European unemployment. It allows us to disentangle some of the factors that played a role in the increase in unemployment. For example, excess wage growth must necessarily be associated with movements along the share-capital relationship. Increases in unemployment that are associated with a shift in the position of that schedule, or that put the economy ox that schedule, cannot be ascribed to just a wage push.

Our approach may then be used to interpret the observed movements in unemployment. We show that one way to do so is to compute the wage gap, i.e. the dixerence between wages and the marginal product of labor at full employment. In the literature it has often been concluded that wage gaps were high in European economies in the second half of the 1970s -and this was associated with unemployment being Classical-, but had disappeared by the mid-1980s -so that

\footnotetext{
${ }^{2} \mathrm{~T}$ he correlation coec cient between labor share changes and real wage changes over the period 1970-90 across these 14 countries is 0.61 .
} 
unemployment had become Keynesian- (see B ean, 1994). O ur model provides an alternative way of computing and decomposing wage gaps, starting from estimates of the labor share relationship. Under our interpretation, a low or negative wage gap associated with high unemployment does not indicate a K eynesian disequilibrium but rather a fall in labor demand that may be due to increased uncertainty, higher markups, higher prices of imported materials, etc. Recently, Blanchard (1998) has argued that the increase in European unemployment cannot be explained by labor supply and user cost shifts alone, so that labor demand shifts are also a necessary ingredient. The model proposed in this paper analyzes the nature of the latter shifts, and our empirical estimates quantify and decompose them.

Given this aim, we analyze the empirical performance of the model, using panel data on a sample of 14 industries in 14 OECD countries, over the period 1973-93. We estimate the relationship between the labor share and a number of its presumed determinants according to the model. In our estimation we follow A rellano and Bover's (1995) recent proposal of a system estimator for panel data, i.e. a generalized method of moments estimator with instrumental variables which employs the information contained in the relationship between the variables in both levels and ..rst dixerences, which helps in raising the ed ciency of the estimation. We ..nd evidence in favor of an empirical relationship between the labor share and the capital-output ratio, e.g. the share-capital relationship, but also signi..cant shifts of the labor share coming from the real price of oil and from factors which cre ate a wedge between the shadow marginal cost of labor and the wage, like labor adjustment costs and union bargaining power.

We then employ the empirical estimates in computing wage gaps in two large economies, the US and Germany, and decompose their evolution according to the theoretical model. The results from this exercise are striking. Only a small fraction of observed movements is the wage gap, whether in Germany or the US, can be attributed to labor-augmenting technical progress or changes in factor costs such as wages and interest rates. Most of those movements indicate shifts in labor demand due to the gap between the shadow cost of labor and the wage. Furthermore, such movements are much more pronounced in Germany than in the US. This is in accordance with the view that some labor market rigidities (most notably employment protection legislation) are likely to increase the dixerence between the shadow cost of labor and wages, and to make the former more volatile.

The paper is structured as follows. Section 2 presents a model of the determination of the labor share. After introducing the stripped-down model, which yields the key relationship between the labor share and the capital-output ratio, we show how the relaxation of various assumptions may axect such relationship. Section 3 presents empirical evidence on the performance of the model on international panel data. Section 4 exploits the empirical relationship to estimate and decompose wage gaps in Germany and the US. Section 5 contains our conclusions. 


\section{Theory}

We start by sorting out, from an analytical point of view, the various factors which may explain variations in the labor share.

\subsection{The labor share and the capital-output ratio}

When trying to explain variations in the labor share we need to depart from the usual assumption of a Cobb-Douglas production function. We show that under the assumptions of constant returns to scale and labor embodied technical progress, there are strong restrictions on the behavior of the labor share, in the sense that there should be a one-for-one relationship between it and the capital-output ratio.

Proposition 1 Assume a constant returns to scale, dixerentiable production function by which output, $\mathrm{Y}$, is produced with two factors of production, capital, $\mathrm{K}$, and labor, L, and labor-augmenting technical progress, B :

$$
Y=F(K ; B L)
$$

Then, under the assumption that labor is paid its marginal product, there exists a unique function $g$ such that:

$$
\mathrm{s}_{\mathrm{L}}=\mathrm{g}(\mathrm{k})
$$

where $S_{L}{ }^{\prime} w L=(p Y)$ is the labor share, with $w$ denoting the wage and $p$ the product price, and $\mathrm{k}^{\prime} \mathrm{K}=\mathrm{Y}$ is the capital-output ratio.

Proof. Let us rewrite the production function as $Y=K f(B L=K)=K f(I)$, where I' $B L=K$. In equilibrium we have:

$$
\frac{w}{p}=B f q(I)
$$

where the prime denotes the ..rst derivative, implying that the labor share is equal to:

$$
S_{L}=\frac{B L f q(I)}{K f(I)}=\frac{\mid f q(I)}{f(I)}
$$

The capital-output ratio is then equal to:

$$
k=\frac{1}{f(I)}
$$

Eliminating I between equations (3) and (4) we ..nd a univariate relationship between $S_{L}$ and $k$ : q.e.d. 
Proposition 1 tells us that even if the production function is not Cobb-Douglas, there is a stable relationship between the labor share and an observable variable, the capital-output ratio. From now on, we shall refer to this relationship as the sharecapital (SK ) schedule (or curve). This relationship is unaltered by changes in factor prices -e.g. wages or interest rates- or quantities, or in labor-augmenting technical progress. That is to say, any change in the labor share which is triggered by those factors will be along that schedule, so that they cannot explain any deviation from the SK relationship, i.e. any residual in equation (1). Note that equations (1) and (3) are essentially the same relationship, but equation (1) is simpler to estimate, since it does not require the computation of $I$, which itself requires us to compute $B$, labor-augmenting technical progress.

Our aim is thus to decompose changes in the labor share between those explained by the capital-output ratio -due to changes in factor prices and laboraugmenting technical progress- and those explained by the residual -i.e., due to other factors discussed below-.

To illustrate Proposition 1 more concretely, let us consider what happens when the production function has a constant elasticity of substitution (CES):

$$
Y=\left((A K)^{\prime \prime}+(B L)^{\prime \prime}\right)^{1="}
$$

where A, B and " are technological parameters.

In this case, the labor share is equal to:

$$
S_{L}=\frac{(B L)^{\prime \prime}}{(A K)^{\prime \prime}+(B L)^{n}}
$$

while the capital-output ratio is simply equal to:

$$
k={\frac{\tilde{A}}{(A K)^{\prime \prime}+(B L)^{\prime \prime}}}^{!_{1=}}
$$

From equations (6) and (7) we have:

$$
\mathrm{s}_{\mathrm{L}}=1_{\mathrm{i}}(\mathrm{Ak})^{\prime \prime}
$$

We therefore see that the relationship between $s_{L}$ and $k$ is very simple in this case. It is monotonic in k; either increasing or decreasing depending on the sign of ": if labor and capital are substitutes, a lower capital intensity will increase the labor share, and conversely if they are complements. For more general production functions, the relationship need not be monotonic, so that the labor share can go up and then down as some variable driving changes in $\mathrm{k}$ (such as real wages or interest rates) varies. 


\subsection{Deviations from a stable SK relationship}

We now analyze the factors that generate deviations from this simple relationship. To do so, let us ..rst de..ne more precisely the SK curve in equation (1), as a relationship between $\mathrm{k}=1 \mathcal{f}(\mathrm{I})$ and' 'If $q(\mathrm{I})=\mathrm{f}(\mathrm{I})$, the employment elasticity of output. Then the economy is on the SK curve in the $\left(k ; S_{L}\right)$ plane if and only if $s_{L}=$ ', i.e. the marginal product of labor is equal to the real wage. We shall distinguish between two types of deviations, depending on whether they cause shifts of the SK curve, i.e. shifts in the $g(:)$ function in equation (1), or movements ox it, i.e. increases in the dixerence between $s_{L}$ and '.

First, the SK curve is stable if only labor-augmenting technical progress axects the aggregate production function. Other factors axecting it, such as $A$ in equation (8) for the CES case, i.e. capital-augmenting technical progress, will shift the SK curve if they are not constant. This is the ..rst possible reason for not having a stable one-to-one relationship between $\mathrm{s}_{\mathrm{L}}$ and $\mathrm{k}$.

Second, there are factors which create a wedge between the real wage and the marginal product of labor. While they do not axect the relationship between ' and $k$, they create a gap between $S_{L}$ and '. These factors therefore do not shift the SK curve, but put the economy ox that schedule in the $\left(k ; s_{L}\right)$ plane. These three sources of movements are illustrated in Figure 5. Let us now discuss each type of deviation in detail.

\subsection{N on-neutralities in the aggregate production function}

We ..rst discuss sources of deviations which shift the SK schedule by changing the aggregate production function in a non-labor-augmenting way. We consider two sources: imported materials and heterogeneity in the composition of the workforce.

\subsubsection{I mported raw materials}

What if there are imported raw materials whose price łuctuates? Unless very restrictive conditions hold, these $\neq u c t u a t i o n s$ will shift the SK schedule in a direction which will depend on the characteristics of the production function.

Let us assume that we have $Y=F(K ; B L ; M)$, where $M$ denotes imported raw materials (say oil), with price $q$. This can be rewritten as $Y=K \mathrm{f}(\mathrm{I} ; \mathrm{m})$; with $I^{\prime} B L=K$, as above, and $m$ ' $M=K . L$ and $M$ are set so as to maximize pro..ts. The ..rst order conditions are:

$$
B f_{1}^{O}(1 ; m)=\frac{w}{p} ; \quad f_{2}^{O}(1 ; m)=\frac{q}{p}
$$

Value added is de.ned as (see Bruno and Sachs 1985, Appendix 2B, for a discussion): $Y^{\prime} Y_{i}(q=p) M$, and the SK curve is now a relationship between 
$\Theta_{L}$; the share of labor in value added given by $\Omega_{L}^{\prime}, w L=\left(p Y^{*}\right)$, and $K^{\prime} K=F^{e}$, the capital-value added ratio. We now have, instead of (4):

$$
K=\frac{1}{f(I ; m) i \frac{g}{p} m}
$$

implying:

$$
\Theta_{L}=\frac{\mid f_{1}^{O}(l ; m)}{R}
$$

Equations (9) and (10) now de..ne $I$ and $m$ as functions of $k$ and $q=p$. Plugging these into equation (11) we get a relationship where $Q_{L}$ is a function not only of $R$ but also of $q=p$.

To get a grasp of the exects at work when the labor share changes as $q=0$ increases, we can dixerentiate equations (9) to (11), to get the change in the labor share holding $\mathrm{K}$ constant:

$$
\frac{d \varepsilon_{L}}{d(q=p)}=\frac{1}{K}^{\tilde{A}} m+\frac{I f_{12}^{\infty}}{f_{22}^{\infty}}+\frac{I m_{1}^{\infty}}{f_{1}^{O} f_{22}^{\infty}} f_{11}^{\infty} f_{22}^{\infty} i \quad\left(f_{12}^{\infty}\right)^{2}
$$

where $f_{11}^{\varpi} f_{22}^{\infty} i \quad\left(f_{12}^{\oplus}\right)^{2}>0$ is the Hessian of the production function.

The ..rst term in the brackets of (12) is positive; it is due to the fact that to maintain a constant ratio between capital and value added as materials prices rise, the labor-capital ratio must rise, which pushes the labor share upwards. The second term is typically negative as long as imported materials increase the marginal product of labor. It measures the fact that given I; imports fall when $q=0$ increases, which reduces the marginal product of labor and therefore wages and the labor share. The third term is also negative. It captures the fall in wages induced by the required increase in the labor capital ratio (taking into account the indirect exect of the induced exect on $\mathrm{m}$ ).

Thus, the price of imported materials shifts the SK schedule in an ambiguous direction. To illustrate this, let us look again at the CES case. Assume the following production function:

$$
Y=\left((A K)^{\prime \prime}+(B L)^{\prime \prime}+(C M)^{\prime \prime}\right)^{1=\prime}
$$

where A, B, C, and " are the technological parameters now. The corresponding expression for the labor share is then: ${ }^{3}$

\footnotetext{
${ }^{3}$ The ..rst-order condition for pro..t maximization with respect to $M$ is: $\left((A K)^{\prime \prime}+(B L)^{\prime \prime}+(C M)^{\prime \prime}\right)^{1=\prime}{ }^{1}, C^{\prime \prime} M " M^{1}{ }^{1}=q=p$. This equation can be solved for $M$; yielding:

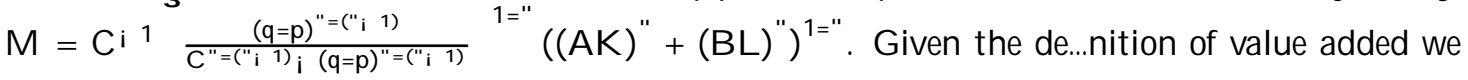




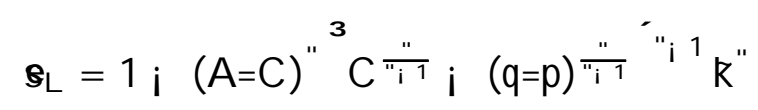

We can thus in principle take into account the impact of changes in the price of imported materials on the labor share by estimating (13) or a linearized variant of it. Note that the SK schedule will shift upwards when $q=p$ rises if and only if " > 0: The more labor is a substitute for capital, the lower the wage fall required to increase I so as to maintain $K$ constant when imported materials fall, and the larger the increase in the labor share.

\subsubsection{Labor heterogeneity}

Until now, we have assumed a homogenous labor force. Recently, considerable attention has been devoted to the changes in the returns to skills that have been observed in the US and other countries since the mid-1970s. These developments may also have axected the labor income share. Thus, we may ..nd it worthwhile to extend our framework so as to distinguish between skilled and unskilled workers. We do so in this subsection, although our data does not allow us to implement such a distinction in our empirical analysis.

How is the labor share axected if there are several types of labor, say skilled and unskilled? In general, there will be again a breakdown in the SK schedule as captured by equation (3). However, under some restrictions in the production function, property (3) still holds. These restrictions are less strong, for example, than those needed for the price of materials not to axect the residual.

Proposition 2 Assume there are three inputs, capital and two types of labor, $L_{1}$ and $L_{2}$, and that the production function is given by:

$$
Y=H\left(K ; G\left(B_{1} L_{1} ; B_{2} L_{2}\right)\right)
$$

where $B_{1}$ and $B_{2}$ are the respective technological parameters, and functions $G(: ;:)$ and $H(: ; ;)$ are homogeneous of degree 1 . Then there exists a one-to-one relationship betwen $\mathrm{s}_{\mathrm{L}}$ and $\mathrm{k}$ :

$$
S_{L}=g(k)
$$

where $\mathrm{g}$ only depends on $\mathrm{H}$ :

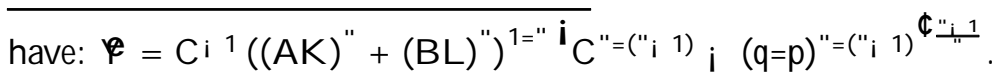

The last term in brackets is decreasing in $q=p$ and captures the exect of the price of materials on total factor productivity de..ned in terms of value added; it is multiplicative in output. The second equation de..nes a functional form similar to equation (5) so that by making the appropriate substitutions in equation (8) we obtain equation (13).
} 
Proof. The .rst-order conditions for maximization with respect to $L_{1}$ and $L_{2}$, with respective wages are $w_{1}$ and $w_{2}$, are:

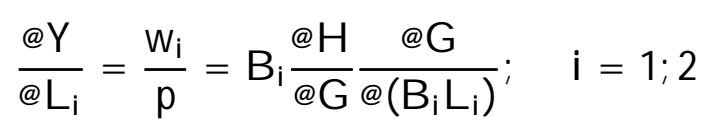

The labor share is then equal to:

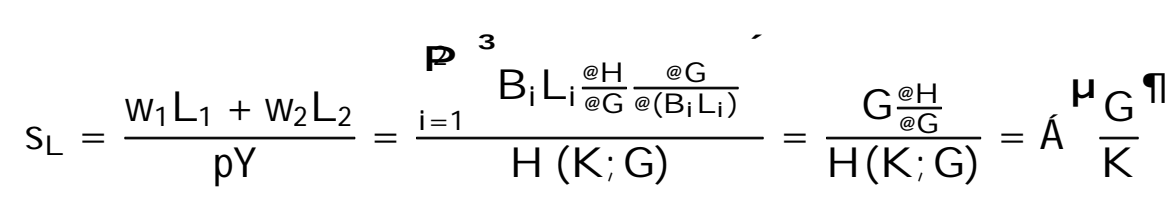

where we have used the homogeneity of $G$ and $H$. The capital-output ratio is then simply equal to $K=H(K ; G)$, which also only depends on $G=K$. Substituting into equation (14) we may then ..nd a relationship between $s_{L}$ and $k$. q.e.d.

Proposition 2 tells us that if skilled and unskilled labor enter production through any aggregate function which is homogeneous of degree one, then there is still a relationship between the labor share and the capital-output ratio, and this relationship is unaxected by relative prices and relative factor supplies. Moreover, it is also unaxected by any change in the relative demand for unskilled labor due to technology, provided such change shows up in $\mathrm{G}$, but not in $\mathrm{H} .4$

It is however often argued (see, for example, K rusell et al. 1997) that there is more complementarity between skilled labor and capital than between unskilled labor and capital. In such case, we can show that the ratio of the wages of the two types of labor would enter the SK relationship (see Appendix A). Unfortunately, that ratio is not observed in our database, thus we will proceed under the working hypothesis that Proposition 2 is valid.

\subsection{Dixerences between the marginal product of labor and the real wage}

We now turn to those factors that put the economy ox the SK curve by generating a gap between the marginal product of labor and the real wage. We consider three of them: product market power, union bargaining, and labor adjustment costs.

\subsubsection{Variations in the markup}

A ssume ..rms are imperfectly competitive, so that there is a markup ${ }^{1}$ of prices on marginal costs. A ccordingly, the optimality condition (2) should be replaced with:

\footnotetext{
${ }^{4} \mathrm{~A}$ particular example where Proposition 2 holds is a production function which is ÇES in capital and a labor aggregate, itself CES in skilled and unskilled labor: $Y=$ $(A K)^{\prime \prime}+\left(\left(B_{1} L_{1}\right)^{1 / 2}+\left(B_{2} L_{2}\right)^{1 / 3}\right)^{n=1 / 2}{ }^{1=}$. This production function includes, as a special case, a CES in all three inputs (when $1 / 2="): Y=\left((A K)^{\prime \prime}+\left(B_{1} L_{1}\right)^{\prime \prime}+\left(B_{2} L_{2}\right)^{\prime \prime}\right)^{1="}$.
} 


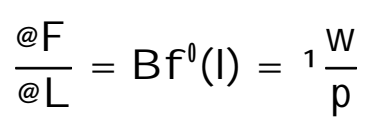

so that we now have:

$$
S_{L}=1 i \frac{\mid f(I)}{f(I)}=1 ; 1,
$$

implying a relationship such as $s_{\mathrm{L}}={ }^{1}{ }^{1} \mathrm{l} g(\mathrm{k})$ : Clearly, if the markup is constant, there should still be a stable relationship between $\mathrm{s}_{\mathrm{L}}$ and $\mathrm{k}$. However, variations in the markup will axect that relationship and will show up in the "residual". For example, if markups are countercyclical, the labor share will tend to be procyclical once we have controlled for $k$ :

Note that the above relationships are actually used by macroeconomists in order to compute the markup (see Hall 1990; R otemberg and Woodford 1991 and 1992; and B énabou 1992). From our point of view, this is unfortunate: many deviations of the labor share from the predicted SK schedule may be due to factors other than the markup. Ideally, one would want to correlate these deviations with direct measures of the markup. In their survey paper on the cyclical behavior of markups, Rotemberg and Woodford (1997) actually discuss various sources of deviation. For instance, they comment on the inclusion of materials in the production function, but assume that materials are a ..xed proportion of aggregate output. ${ }^{5}$

Recall now Figure 5, which summarizes the discussion up to this point. It depicts the SK curve in the $\left(k ; S_{L}\right)$ plane, showing that increases in wages imply movements along the curve, but changes in the price of materials cause shifts of the curve itself, while variations in the markup put the economy ox the schedule.

\subsubsection{B argaining}

A nother source of deviations from the SK curve is the existence of bargaining between ..rms and workers. Indeed, increases in the labor share are customarily interpreted as increases in workers' bargaining power, and it is often hastily concluded that employment consequently has to decline. The issue is more complicated, though, because everything depends on what bargaining model is assumed.

Right to manage Under the right-to-manage model, ..rms and unions ..rst bargain over wages and then ..rms set employment unilaterally, taking wages as given. This model is widely seen as a good description of how bargaining actually takes

\footnotetext{
${ }^{5}$ T hese authors also mention other deviations ignored here, like overhead labor, ..xed costs in production, increasing marginal wages, or variable exort. However, their paper's focus is on the cyclicality of the markup, rather than on the shifts in labor demand and its exects on unemployment, as ours.
} 
place in many countries (see, e.g., Layard et al. 1991, chapter 2). But then, because ..rms are wage takers when setting employment, the marginal product equation (2) remains valid, and so does Proposition 1 . Under this model, changes in the bargaining power of workers may move the labor share, but along the SK curve, not away from it, in a direction which depends on the elasticity of substitution between labor and capital (see equation (8) for the CES case). M ore speci..cally, an increase in workers' bargaining power creates a wage push that increases $k$ as ..rms substitute capital for labor. But the labor share may rise or fall depending on the slope of the SK curve (i.e. the elasticity of substitution between labor and capital), and the relationship between $\mathrm{k}$ and $\mathrm{S}_{\mathrm{L}}$ is unaxected.

We can represent the right-to-manage model as follows. Wages are ..rst set to maximize the following Nash maximand:

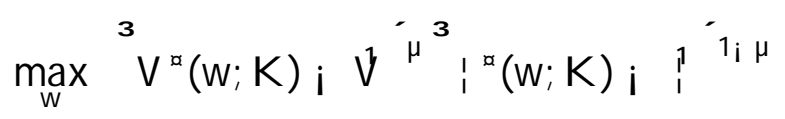

where $V{ }^{x}(w ; K)$ and $\mid{ }^{x}(w ; K)$ are reduced-form union utility and pro..ts, respectively, while $\vec{V}$ and ${ }_{1}^{1}$ are the appropriate threat points. $\mu$ is a parameter weighting the two objective functions, which can be labeled as union bargaining power. In the second stage of the game, the ..rm determines employment by maximizing:

$$
I^{x}(w ; K)=\max _{L} i(w ; L ; K)=p F(K ; B L) ; w L
$$

This de. nes an optimal employment level, $L^{a}(K)$, a reduced form pro..t, $\left.\right|^{x}(w ; K)$, and a reduced form utility, $V^{\natural}(w ; K)=V\left(w ; L^{\natural}(K)\right)$. Now, the ..rst-order condition for pro..t maximization is clearly (2), so that (3) and (4) are still valid. Thus the relationship between $\mathrm{s}_{\mathrm{L}}$ and $\mathrm{k}$ is unaxected by $\mu^{6}{ }^{6}$

$\mathrm{E} ₫$ cient bargaining If, on the other hand, ..rms and workers bargain over both wages and employment, they will set employment in an ec cient way, implying that the marginal product of labor is equal to its real opportunity cost $(w=p)$ :

$$
B f(I)=\frac{w}{p}
$$

In the sort run, an increase in the bargaining power of workers does axect the labor share but is not rełected in employment. In the long-run, adjustment of the capital stock indeed implies that changes in the bargaining power of workers also axects employment.

\footnotetext{
${ }^{6} \mathrm{Here}$ we have assumed that bargaining over wages takes place after the capital stock is determined. Our conclusions would be unaxected if instead the capital stock was determined by the ..rm after wage setting, or even if bargaining took place over the capital stock, as long as employment is determined by pro..t maximization given wages.
} 
How does ed cient bargaining axect the position of the economy in the $\left(k ; s_{L}\right)$ plane? A simple Nash bargaining model would imply that the wage is a weighted average of the average product of labor and its opportunity cost, with the weight on the average product being equal to workers' bargaining power, $\mu$ (see, e.g., Blanchard and Fischer 1989, chapter 9):

$$
\frac{w}{p}=\mu \frac{B f(I)}{I}+(1 ; \mu) \frac{w}{p}
$$

This in turns implies that $w=p=\mu(B f(I)=1)+(1 ; \mu) B f q(I)$, hence (recalling the de. nitions of $S_{L}$ and I):

$$
\mathrm{S}_{\mathrm{L}}=\mu+(1 ; \mu) \frac{\text { If } 9(\mathrm{I})}{\mathrm{f}(\mathrm{I})}=\mu+(1 ; \mu)^{\prime}=\mu+(1 ; \mu) g(\mathrm{k})
$$

This is a well-de.ned relationship between the labor share and the capitaloutput ratio. It has the same properties as the SK curve, but is above it, reł ecting the fact that workers are paid more than their marginal product. As ' $<1$, an increase in workers' bargaining power shifts that relationship upwards, thus putting the economy further ox the SK curve: the labor share tends to increase given the capital-output ratio. The latter is unchanged, as it is pinned down by the equality between marginal product and the alternative wage. Thus the labor share unambiguously increases. Increases in workers' bargaining power reduce the sensitivity of the labor share to the capital-output ratio according to this relationship. For example, in the CES case we get:

$$
\mathrm{s}_{\mathrm{L}}=1 \mathrm{i}(1 ; \mu)(\mathrm{Ak})^{\prime \prime}
$$

\subsubsection{Labor adjustment costs}

We now consider how the introduction of labor adjustment costs alters the SK relationship. This is of interest if we want to use our approach to understand the European experience, given that regulation imposes high hiring and ...ing costs there. Adjustment costs axect the behavior of the labor share for two reasons. First, the labor share is no longer equal to wages divided by value added. Labor costs now consist of two parts: wage costs and non-wage adjustment costs. The adjustment costs will enter the labor share if they are a resource cost which uses labor -for example if new hires have to be recruited by an employment agency, or if they have to be trained by the..rm's existing workforce, thus diverting it from direct productive activity-. They will also enter the labor share if they are payments from the ..rm to the worker, as is the case for severance payments. Other components of ...ing costs such as court and arbitration procedures will have a strong labor cost component. 
Second, adjustment costs introduce a gap between the marginal revenue product of labor and the wage, since the relevant marginal cost of labor is no longer equal to the wage. More precisely, the marginal cost now consists of three terms: the current wage, the current marginal adjustment cost generated by an extra unit of labor, and the shadow expected future marginal adjustment costs generated by that unit. Let us discuss the latter two terms in turn.

The second component will push the marginal cost of labor above the wage when the ..rm is hiring and below it when it is ..ring. More speci..cally, if we assume that real labor adjustment costs are a convex function $A C(\phi L)$, where $\phi L$ is the change in employment, and if the future is negected (say because the discount rate is in..nite), we have that $B f q()=w+A C q \phi L)$, where $A C q \phi L)>0$ if $\phi L>0$ and $A C 9 \phi L)<0$ if $\phi L<0$ (see, e.g., B entolila and Bertola 1990). If adjustment costs are not part of the labor costs included in the labor share, this implies that $S_{L}>g(k)$ if $\phi L<0$ and $s_{L}<g(k)$ if $\phi L>0$, thus suggesting that one should add a decreasing function of the change in employment to our explanatory variables. In Appendix A we show that this intuition is roughly valid as well when we take into account that adjustment costs also enter labor costs.

As to the shadow expected future marginal adjustment costs, they depend, among other things, on the degree of uncertainty. Higher uncertainty might be expected to increase the likelihood that a worker be ... shadow cost of labor and pushing the economy further below the SK curve. This is not unambiguous, though. In principle, as in the case of investment (see Nickell 1977), an increase in uncertainty may well increase incentives to hire. However, if we ..nd the opposite exect more plausible, then we should expect a negative relationship between uncertainty and the labor share, given the capital-output ratio.

From an empirical point of view, the preceding arguments indicate that both taking current adjustment costs into account in the labor share, and taking marginal adjustment costs -current and future- into account in the marginal cost of labor, should lead to adding a decreasing function of $\phi L$ and a function of perceived uncertainty, 3/4, as explanatory variables for the labor share, i.e.:

$$
S_{L t}=f\left(K_{t} ; \phi L_{t} ; 3 / 4\right)
$$

where it is likely that $f_{2}^{0}(:)<0, f_{3}^{0}(:)<0$. 


\section{Evidence}

We now investigate empirically the factors driving the evolution of the labor share in 14 OECD countries since 1970, following our model. Data availability, however, precludes analyzing all the variables which are relevant according to the model. We focus on four sources of variation: movements along the SK relationship i.e., shocks whose exect on $s_{L}$ is entirely mediated by $k$, such as changes in the prices of capital and labor, and labor-augmenting technical progress-; one shifter of the SK curve, namely changes in the price of raw materials; and two sources of movements ox the SK schedule, namely changes in union bargaining power and labor adjustment costs. We start by documenting a few stylized facts present in the data, we then discuss the equation to be estimated and the econometric techniques used, and we ..nally show the empirical results.

\subsection{Stylized facts}

The SK schedule is a technological relationship, and so it is more appropriate to investigate it at the industry than at the country level. Therefore, we use industry data from the OECD International Sectoral Data Base (ISDB), which includes information on output, employment, capital, and factor shares for 14 OECD countries over the period 1970-93, disaggregated at the 1- or 2-digit level. The set of industries analyzed does not span the whole economy, but comes close to doing so. A ppendix B provides details on the database.

Our key variables are the labor share $\left(\mathrm{s}_{\mathrm{L}}\right)$ and the capital-output ratio $(\mathrm{k})$. The variable $s_{L}$ is de..ned as the share of labor in nominal value added net of indirect taxes and $k$ is the ratio of the real capital stock to real value added. In other words, they correspond to $\mathrm{g}$ and $k$, as de. ned in the theory section, although we will omit the e symbol for simplicity. Table 2 presents the overall statistics of these two variables for all industries, countries, and years in the sample. ${ }^{7} \quad$ Table 3 shows 1973-93 averages (the sample period used in the econometric estimates, see below) for $s_{L}$ and $k$ by industry and by country. For countries, averages for the whole economies' business sector are shown as well. The dixerence between these and the ISD B sample averages stem from the absence of a few sectors (sometimes only for certain years), and from the inclusion of an imputation for the labor income of the self-employed in the former. ${ }^{8}$ Interestingly, within our sample, both variables vary more widely across industries than across countries: the range for the labor share, for example, goes from $20 \%$ in agriculture to $75 \%$ in machinery. These numbers help us make the case for the industry approach to the data followed in this section.

\footnotetext{
${ }^{7} \mathrm{~T}$ he remaining variables will be introduced below.

${ }^{8}$ Descriptive statistics of the labor share in our sample when it is adjusted for the labor remuneration of the self-employed appear in Table A 2 of A ppendix B.
} 


\subsection{Empirical speci..cation}

For empirical purposes, we assume the following multiplicative form:

$$
S_{L ; i j t}=g\left(k_{i j t} ; S_{i j t}\right) h\left(X_{i j t}\right)
$$

where the subindexes denote: industries $(\mathrm{i}=1 ;:: ; 114)$, countries $(\mathrm{j}=1 ;:: ; 14)$, and time $\left(t=1973 ;: ; ;\right.$ 1993).$^{9}$ Here $g(k ; S)$ captures the SK schedule, which is axected by $S$. Following section 2.3, and given data limitations, under our empirical speci..cation $S$ only contains the national real price of imported oil, $q_{j}=p_{j}$.

On the other hand, $h(X)$ captures discrepancies between the marginal product of labor and the wage -wage bargaining, adjustment costs, etc.- which may move the economy ox the SK relationship. Following section 2.4, X includes three variables. First, the exect of current labor adjustment costs is captured through the industry employment net growth rate $\left(\$ \ln n_{i j}\right){ }^{10}$ Although we would like to separate out gross increases from gross reductions in employment, so as to allow for the asymmetry between hiring and ..ring, these $\ddagger$ ows are not available in our dataset. Second, the exect of future expected adjustment costs is captured through a measure of uncertainty: the standard deviation of the growth rate of industry output $(3 / 4 \mathrm{j})$. Considering the length of the sample period, we compute this variable as a 5-year, backward-looking, moving average (denoted by »). Lastly, the eaect of workers' bargaining power $(\mu)$, which might matter in an eф cient bargains setup, is captured by the number of labor conłicts nationwide, normalized by the number of employees in the preceding year. This variable is also measured as a 5-year backward-looking moving average and it is denoted by $\mathrm{IfCr}_{j} .{ }^{11}$

Our model suggests that the coec cients on the variables in $X$ might depend on the type of labor market institutions prevailing in each country, namely labor adjustment costs and union power. For example, the change in employment and uncertainty are likely to have a greater impact in countries where adjustment costs are important, i.e., which have more stringent employment protection regulations. We lack enough degrees of freedom to allow for full-łedged interactions, but we can capture sizable dixerences through simple dummies. Thus, we interact the variables which would enter if adjustment costs are important, $\$$ In $n_{i j}$ and $4_{4 j}$, with a dummy variable, labeled rigid, which is equal to one if adjustment costs are relatively high in the country and zero otherwise. The grouping of countries

\footnotetext{
${ }^{9} \mathrm{~T}$ he data start in 1970, but the period of estimation is 1973-93 because we lose the ..rst 3 years due to the dating at $\mathrm{t}-2$ of instrumental variables in ..rst dixerences.

${ }^{10} \mathrm{E}$ mployment here refers to the number of employees.

${ }^{11}$ We also tried the the number of workers involved and work-days lost due to conłicts as alternative numerators of the conłict rate. As to the timing of Icr, were tried a 5-year moving average of output volatility centered around year $t$ and a 3-year forward-looking moving average. The empirical results reported below were scarcely sensitive to these variations.
} 
follows the information on severance pay and notice periods in Layard et al. (1991, p. 420). A ustralia, Canada, Denmark, J apan, the Netherlands, the UK, and the US are classi..ed as having łexible labor markets, and the remaining countries as having rigid ones.

As to the exect of bargaining power $(\mu)$, at least two dimensions need to be taken into account. First, the higher the degree of centralization of wage bargains, the higher the expected exect of union power on the wage share. The reason is that higher centralization will move the economy closer to the eq cient bargains model since national unions are likely to internalize the exect of their wage choice on national employment (Calmfors and Dri..ll 1988). Secondly, the economy will also be closer to the ed cient bargains benchmark the higher the degree of inter-union and inter-..rm coordination (Layard et al. 1991). Thus, we distinguish between countries with varying degrees of corporatism, broadly de..ned, e.g.: (a) a high degree of both centralization and coordination, labeled as corp2 (Denmark, Finland, Norway, and Sweden); (b) high centralization but low coordination, labeled as corp1 (A ustralia, B elgium, France, Germany, Italy, and the Netherlands); and (c) a low degree of both centralization and coordination (Canada, J apan, the UK, and the US). Our ranking on the degree of centralization of wage bargains follows the corporatism index of Calmfors and Dri...l (1988), and the composite index of the degree of inter-union and inter-..rm coordination follows Layard et al. (1991, p. 419)..$^{12}$

A gain for empirical purposes, we impose further structure by assuming that the functions $g(:)$ and $h(:)$ in equation (15) are also multiplicative, i.e.:

$$
\begin{aligned}
& g\left(k_{i j t} ; S_{i j t}\right)=k_{i j t}^{-1} \frac{q_{j t}}{p_{j t}}{ }^{-{ }_{2}} \\
& h\left(X_{i j t}\right)=\exp _{k=3}^{\tilde{A}} X^{6} x_{i j t}^{k} !
\end{aligned}
$$

where $X_{i j t}=\left(\phi \ln n_{i j t} ;{ }^{3} / 4_{j} t ; \mid f^{f} c_{j t} ; v_{i j t}\right)$, and $v$ is a residual term, so that ${ }^{-}{ }_{6}{ }^{\prime} 1$. Now substitute equations (16) and (17) into (15) and take logs, to arrive at the basic estimated equation:

\footnotetext{
${ }^{12}$ The corporatism (CORP) ranking is as follows (from less to more, e.g. 1 to 14): Canada, the US, J apan, Italy, the UK, France, A ustralia, Belgium, the Netherlands, G ermany, Finland, Denmark, Sweden, and Norway. For coordination (COORD), we add up the scores assigned to countries for union (UNCD) and employer (E M CD) coordination by Layard et al. (1991), both going from 1 (low) to 3 (high), obtaining the following scores: Canada, the UK, and the US (2), Australia and Italy (3), B elgium, France, J apan, and the Netherlands (4), Germany (5), and Denmark, Finland, Norway, and Sweden (6). Thus, corp2 includes countries with CORP $>10$ and COORD $>5$, and corp1 those with $5<$ CORP $<11$ (plus Italy) and $2<$ COORD $<6$.
} 


$$
\begin{aligned}
& \ln s_{L ; i j t}=,+{ }_{i}^{x}-{ }_{1 i}\left(d_{i} \ln k_{i j t}\right)+{ }_{i}^{x}-{ }_{2 i}\left(d_{i} \ln \left(q_{i t}=p_{j t}\right)\right) \\
& +{ }_{3} \$ \ln n_{i j t}+{ }_{4}{ }_{4 j t}+{ }^{-}{ }_{5} f^{f} c r_{j t}+v_{i j t}
\end{aligned}
$$

where, is a constant term. Note that the coec cients on the main technology variables are allowed to vary by industry through interactions with the $d_{i}$ industry dummies.

Lastly, to allow for the dixerential exects of country-speci..c labor market institutions discussed above, we also estimate the following extended equation:

$$
\begin{aligned}
& \left.\ln s_{L ; i j t}=,+{ }_{i j}^{x}-d_{i} \ln k_{i j t}\right)+{ }_{-}^{x}-{ }_{2 i}\left(d_{i} \ln \left(q_{i t}=p_{j t}\right)\right) \\
& +{ }^{-}{ }_{3} \phi \ln n_{\mathrm{ijt}}+{ }_{3}^{-0}\left(\text { rigid } \phi \ln \mathrm{n}_{\mathrm{ijt}}\right)+{ }_{4} \psi_{4 \mathrm{jt}}+{ }_{4}^{-0}\left(\text { rigid } \psi_{4 \mathrm{jt}}\right) \\
& +{ }^{-}{ }_{5} I^{f} C r_{j t}+{ }_{5}^{-0}\left(\operatorname{corpl} I^{f} C r_{j t}\right)+{ }_{5}^{-\infty}\left(\operatorname{corp} 2 I^{f} c r_{j t}\right)+v_{i j t}
\end{aligned}
$$

\subsection{Econometric methods}

\subsubsection{General issues}

Equation (18) is estimated using panel data techniques, where individual units of observation are industry-country units. Also, since some observations are missing -either at the beginning or the end of the sample period-, we have an unbalanced panel (see Table A 1).

The labor share and the capital-output ratio are jointly determined variables appearing in the basic SK relationship, which is a ..rst order optimality condition. When there are adjustment costs, the same is true of the employment growth rate. These variables are jointly endogenous and are therefore instrumented, since ordinary least squares estimation would be biased. We discuss the choice of instrumental variables below.

We expect the presence of individual ..xed exects in the equation. If these are omitted and correlated with any of the regressors included, the resulting estimates are biased. A standard way of solving this problem is to estimate the equation in ...rst dixerences. It is then typical to use predetermined variables in levels, like e.g. lags of the regressors, as instrumental variables. However, the absence of information about the parameters of interest in the levels of the variables usually causes the loss of a substantial part of the variation in the data, often resulting in poor estimates. This problem can, however, be overcome if we are willing to assume that some of the regressors have a constant correlation with the ..xed exects, an assumption whose validity only requires stationarity in mean of the regressors 
given the exects, which moreover can be tested through the overidentifying restrictions. A rellano and Bover (1995) note that, in this case, the ..rst dixerences of the predetermined variables are valid instruments for the equations in levels. In exect, they propose, in addition to using instruments in levels for the equations in ..rst dixerences, to use instruments in ..rst dixerences for the equations in levels. The model behind this ..rst-dixerences plus levels, or system, estimator is an intermediate case between the ..xed-exects model, in which all explanatory variables are potentially correlated with the exects, and the random exects model, in which none is. A rellano and Bover (1995) show that the system estimator may yield large et ciency gains vis-à-vis the pure ..rst-dixerence estimator (see also Blundell and Bond, 1997).

We follow this proposal here. The estimation is carried out with the dynamic panel data program DPD 98, which implements the A rellano-B over system estimator. This is an extension of the Generalized M ethod of M oments (GMM ) procedure proposed by A rellano and Bond (1991), which exploits the appropriate orthogonality conditions for the chosen instruments, minimizing the dixerence between the sample moments and their zero population value.

\subsubsection{Techniques}

We can rewrite equation (18) in the form: $:^{13}$

$$
y_{k t}=-a_{k t}+t_{k}+v_{k t}
$$

where, within this subsection, subindex $k$ denotes an $(i ; j)$ industry-country unit

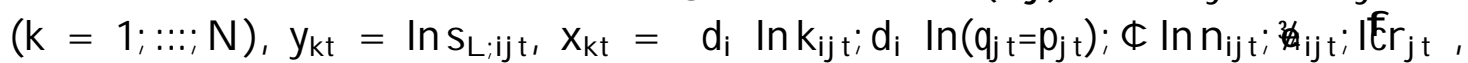
$v_{k t}=v_{i j t}, t_{k}$ denotes ..xed exects, and ${ }^{-}$the parameter vector. The number of units is $N=165$ and $t=1 ;: ; ; T_{k}$, where $T_{k} \cdot 21$ is the number of time periods available on the k-th unit. The $v_{k t}$ are assumed to be independently distributed across units with zero mean, but arbitrary forms of heteroskedasticity across units and time are allowed for.

The $T_{k}$ equations for unit $k$ can be written in the stacked form:

$$
y_{k}=x_{k}{ }^{-}+q_{k} t_{k}+v_{k}
$$

where $x_{k}$ is a data matrix of the time series of the $x^{\prime} s$ and $q_{k}$ is a $T_{k} f 1$ vector of ones. We compute the following linear GMM estimator of ${ }^{-}$:

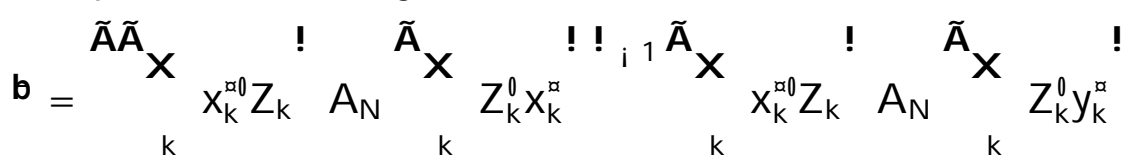

\footnotetext{
${ }^{13}$ T his follows A rellano and B over (1995) and A rellano and B ond (1998) closely.
} 
where

$$
A_{N}=\frac{1}{N}_{k}{ }_{k} Z_{k}^{0} H_{k} Z_{k}{ }^{!} \text {i }
$$

and $x_{k}^{a}$ and $y_{k}^{\alpha}$ denote a transformation of $x_{k}$ and $y_{k}$, in our case a combination of ...rst dixerences and levels. $Z_{k}$ is a matrix of instrumental variables and $H_{k}$ a weighting matrix. We report two-step estimates for coeł cients and t-ratios, which use $\mathrm{H}_{\mathrm{k}}=b_{\mathrm{k}}^{a}$, where $\boldsymbol{w}_{\mathrm{k}}^{a}$ are one-step residuals, since it is more ec cient when the $\mathrm{V}_{\mathrm{kt}}$ are heteroskedastic (W hite, 1982). ${ }^{14}$

\subsubsection{Instrumental variables and speci..cation tests}

Given our assumptions, there is a set of moment conditions relating to equations in ..rst dixerences and another set relating to equations in levels, which are combined to obtăin the ed cient GMM estimator. The instrument set is then of the form: $Z_{k}=\begin{array}{cc}Z_{k}^{D} & 0 \\ 0 & Z_{k}^{L}\end{array}$, where $Z_{k}^{D}$ is the matrix of instruments for the equations in ..rst dixerences and $Z_{k}$ is that for the equations in levels.

We treat the labor share, the capital-output ratio, the change in employment, and the real oil price as potentially endogenous. T wo variables, the proxies for labor conłicts and uncertainty -constructed as backward-looking moving averages- are treated as predetermined.

We use three types of instruments. The ..rst type consists of lagged regressors, which can be taken as predetermined, i.e. the capital-output ratio and the rate of change in employment $\left(\ln \mathrm{k}_{\mathrm{ij}}\right.$ and $\left.\$ \ln \mathrm{n}_{\mathrm{ij}}\right)$. In the ..rst-dixerenced equations, we use the level of the real capital stock $\left(\ln \mathrm{K}_{\mathrm{ij}}\right)$ rather than $\ln \mathrm{k}_{\mathrm{ij}}$ itself, which is more likely to be predetermined. This is, however, not feasible in the levels equations, due to the assumption of stationarity of the (dixerenced) instruments. We also added the square $\log$ capital stock, $\left(\ln K_{i j}\right)^{2}$, to capture potential nonlinearities. Since dixerencing induces a ...rst-order moving average of the residuals, we use the second lags of these variables. As a second type of instrument we use the contemporaneous values of the predetermined regressors, $f^{f} \mathrm{cr}_{j}$ and ${ }_{4 j}$, plus the ..rst and second lag of the latter. We also include the growth rate of national GDP $\left(ф \ln y_{j}\right)$.

For lack of degrees of freedom, we cannot interact all instruments with industry dummies, so we do it only for the lagged capital stock (capital-labor ratio in the levels equations), the labor conłict rate, and the growth rate of GDP. In the case of the extended speci..cation in equation (19), when we include in the estimated

\footnotetext{
${ }^{14} \mathrm{~A}$ rellano and B ond (1991) show that, in ..rst-dixerence estimation, two-step estimators of asymptotic standard errors may be too small. However, results in Blundell and Bond (1997) indicate that this is much less true for the system estimator used here.
} 
equation a given dummy variable interacted with any of the regressors, we also add that dummy to the instrument set.

The speci..cation is checked by means of the Sargan statistic (ST), a test of overidentifying restrictions for the validity of the instrument set, which is distributed as a $\hat{A}^{2}$ with degrees of freedom equal to the number of instrumental variables minus the number of parameters. ${ }^{15}$ Since the set of instruments used for the equations in ..rst dixerences is a subset of that used in the system of ..rst-dixerenced and levels equations, we also report a more speci..c test of the additional instruments used in the levels equations, the Dixerence Sargan test (DS), which compares the Sargan statistics for the system estimator and the corresponding ...rst-dixerenced estimator. ${ }^{16}$

We also report a statistic for the absence of second-order serial correlation in the ..rst-dixerenced residuals, $v_{\mathrm{kt}}$ i $\boldsymbol{v}_{\mathrm{k} ; \mathrm{t}_{\mathrm{i}} 1}$, labeled $\mathrm{m}_{2}$. This is based on the standardized average residual autocovariances, which are asymptotically $N(0 ; 1)$ variables under the null of no autocorrelation, and should not be signi..cantly dixerent from zero if the residuals in levels are serially uncorrelated (note that, due to dixerencing, ..rst-order autocorrelation is expected ex-ante).

\subsection{Empirical results}

Table 4 contains the estimates of our basic speci..cation, equation (18)- They provide support for the SK schedule: the capital-output ratio shows up signi..cantly, which suggests the presence of departures from the Cobb-D ouglas production function. The covariation is positively signed in 11 out of 14 industries, suggesting that labor and capital are most often complements, rather than substitutes (see equation (8) for the CES case). The shifter of the SK relationship we have included, the real oil price, is also signi..cant, attracting negative coec cients (except for agriculture) and thus resolving the theoretical ambiguity (see equation (12) for the CES case).

Turning to movements ox the SK curve, in Table 4 both variables capturing the exects of labor adjustment costs, the employment growth rate and output uncertainty are signi..cant, showing the expected negative sign. Surprisingly, the

\footnotetext{
${ }^{15}$ If $A_{N}$ has been chosen optimally for any given $Z_{k}$, the statistic

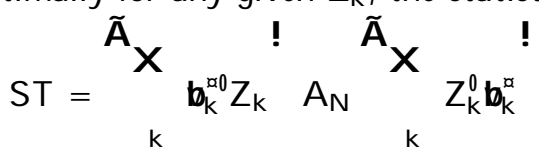

is asymptotically distributed as a chi-square with as many degrees of freedom as overidentifying restrictions, under the null hypothesis of the validity of the instruments. See Arellano and B ond (1991).

${ }^{16}{ }^{2}$ et $S T_{d} \gg \hat{A}_{q_{1} ;}^{2}$ be the Sargan statistic for the ..rst-dixerence estimation, with $q_{1}$ its number of instruments, so that $q_{1}+q_{2}$ is the number of instrument in the system estimation, and $n$ the number of parameters. The Dixerence Sargan test is distributed as DS $=\mathrm{ST}_{i} \mathrm{ST}_{d}$ » $\hat{\mathrm{A}}_{\mathrm{q}_{2}}^{2}$.
} 
labor con¥ict rate, our proxy for workers' bargaining power, attracts a negative coed cient. One interpretation of this ..nding relies on delayed responses to wage pushes (Caballero and Hammour 1998, see section 4 below). ${ }^{17}$ In any event, as we shall see, the sign on this variable depends on the degree of corporatism in the country.

Test statistics for the validity of the instrument set and for second-order correlation in the residuals do not show any problems, although the Sargan test for the validity of the extra instruments used in the system estimation, vis-à-vis the reduced set for the ..rst-dixerenced one, is passed at the margin.

Table 5 provides the estimation results for the extended speci..cation in equation (19). Dixerent columns include a dixerent set of regressors. In column (1) we interact the employment growth rate with the labor market rigidity dummy and obtain that, as expected, it is signi..cant only in countries with more rigid labor markets. Nevertheless, column (2) shows that output volatility, introduced so as to capture the impact of future expected adjustment costs, does not appear to have a signi..cantly dixerent exect in countries with ‡exible and rigid labor markets. When we add the corporatism dummies interacted with the labor confict rate, we ..nd, in column (3), that the negative sign found in Table 4 comes from countries with relatively centralized bargaining but only a moderate amount of overall interunion and inter-..rm coordination. The exect is, on the other hand, positive for both countries with decentralized bargaining and low coordination, and those with highly centralized bargaining and high coordination. R egarding centralization, this ..nding is reminiscent of the hump-shaped relationship between centralization and economic performance found by Calmfors and Driф II (1988). As to coordination, in a cross-section analysis of 20 OECD countries, Nickell (1997), ..nds that union coverage tends to raise unemployment, but this is oxset if unions and employers can coordinate their bargaining activities. The dixerences we have uncovered regarding the impact of labor conficts in coordinated vs. uncoordinated countries is a new interesting ...nding, relevant to this debate. At this stage of our research, we lack a simple explanation, but we believe this fact deserves further research.

In column (4) we can see that the results in columns (1) and (3) are robust to the joint introduction of the interactions added in those two columns. On the other hand, further addition of the interaction of output volatility with the rigidity dummy in column (5), while keeping all signs unchanged, lowers the signi..cance of several coeф cients.

We should note that our results may be axected by measurement error. In our

\footnotetext{
${ }^{17} \mathrm{~A} n$ alternative interpretation would require us to implicit model the cyclical behavior of bargaining power. In Goodwin's (1967) model of business cycles, unions tend to strike when the capital share goes up. In his own words: "The improved pro..tability carries the seed of its own destruction by engendering a too vigorous expansion of output and employment, thus destroying the reserve army of labor and strengthening labor's bargaining power" (p. 58).
} 
data, $s_{L}$ is computed as the share of the remuneration of employees in value added. In general, part of the remuneration of the self-employed is a return to labor rather than to capital. However, there is no natural way of imputing that part. One way of doing it is to assume that the self-employed earn the same wage as employees. However, typical calculations imply that the labor remuneration of self-employed labor is actually lower than that of employees, which is not so surprising given that, for instance, social security taxes on the latter are generally much higher than on the former. Thus, as a rough approximation, we have assumed that the self-employed earn two-thirds as much as employees (an assumption which gives estimates for the labor share which are close to those reported, for example, by Eurostat in its European Economy review). Descriptive statistics of the sample when the adjusted labor share are given in Table $\mathrm{A} 2$ of A ppendix $\mathrm{C}$.

In A ppendix C we present the estimation results for equation (18), using the adjusted labor share, $\mathrm{s}_{\mathrm{L}}^{\mathrm{p}}$. Note that the sample size is now close to one-fourth smaller than before, because average indirect tax rates, which are needed for computing the adjusted labor share, are missing more often than the remaining variables. This tends to render the econometric results less informative than those for the unadjusted labor share. Also, we do not expect to ..nd exactly the same coet cients as with the unadjusted labor share, since, for example, both ...ring costs and union power axect employees but not the self-employed. A comparison of the results in Tables 4 and 5 with those of Tables A 3 and A 4 reveals a drop in the individual signi...cance of the individual coet cients on the capital-output ratio and the real price of oil. The signs of the coet cients on the shifters ox the SK schedule are maintained, with the coed cients on the change in employment and output volatility generally becoming stronger, and those on labor conłicts becoming weaker.

In sum, we have tested our model of the determination of the labor share, albeit without imposing tight restrictions from the theory. The results con..rm that a share-capital schedule exists, that the real price of oil shifts it, and that there are signi..cant deviations from it due to gaps between the marginal product of labor and the wage, arising from labor adjustment costs and union power. We now turn to a direct application of these empirical results.

\section{A pplication: wage gaps revisited}

\subsection{A nother look at the wage gap}

Having checked that the theory is a reasonable guide to the behavior of the labor share, we now employ it in trying to shed some light on the causes of European unemployment, by revisiting the so-called wage gap (see Artus, 1984; B runo and Sachs, 1985). The wage gap approach typically takes the evolution of wages as 
exogenous and compares them to the marginal product of labor at full employment. That is, recalling the production function $Y_{t}=F\left(K_{t} ; B_{t} L_{t}\right)$, at time the wage gap is de..ned as:

$$
W G_{t}=\frac{W_{t}=p_{t}}{B_{t} F_{2}^{0}\left(K_{t} ; B_{t} L^{2}\right)} \text { i } 1
$$

where $\mathrm{L}^{\mathrm{l}}$ is the full employment level. Then, assumptions are typically made about the production function and the behavior of productivity in order to estimate a path for the denominator. This approach thus essentially amounts to looking at the evolution of wages vis-à-vis labor productivity. This is quite close to looking at the labor share, so that in most of continental Europe, where the labor share has risen and then fallen to its 1970 level (see Figure 4), it is generally concluded that the wage gap has disappeared. The question is then how to reconcile this with the persistence of high unemployment. In the wage gap literature, a low wage gap is generally interpreted as an indication that most unemployment is Keynesian, i.e. due to persistent slack associated with the failure of nominal prices and wages to adjust. Given the persistence of high unemployment in Europe, we ..nd that interpretation hard to believe.

How can our approach shed light on this issue? First, we can provide a new estimate of the wage gap, based on our analysis of the labor share, which may potentially dixer from those available in the literature. Second, we are able to decompose changes in the wage gap in a new way. We have shown that we can break down movements in the labor share into three components: (i) movements along the SK schedule, which represent the optimal adjustment of ..rm's desired employment to changes in prices and labor-augmenting technical progress; (ii) movements of the SK schedule itself, which may arise from non-neutral technical progress, or equivalently changes in the price of imported materials; and (iii) movements ox the SK schedule, which represent discrepancies between the marginal product of labor and the wage. Possible sources of such discrepancies include adjustment costs, wage bargaining, and markups.

The ..rst source of shocks -movements along the SK schedule-generates a negative relationship between the wage gap and employment: it simply captures the fact that, given the production function, the marginal product of labor is decreasing with employment.

The second source of shocks - movements of the SK curve- will typically axect the marginal product of labor both at full and at current employment. It does not generate any clear correlation between employment and the wage gap. Both can go either way, and this depends on how wages react to shocks. However, if the elasticity of the marginal product of labor with respect to employment is unchanged, then such shocks can only increase the wage gap if at the same time unemployment increases. In that case they will generate the same correlation between the two 
variables as the ..rst source of shocks.

The last source of shocks -those putting the economy ox the SK curve, such as an increase in uncertainty under labor adjustment costs- axects the gap between the marginal product of labor and the wage. An increase in that gap tends to reduce both employment and wage, while increasing the marginal product. Therefore we will observe an increase in unemployment associated with a fall in the wage gap. This source of shocks thus generates a negative correlation between these two variables.

A nalytically, this argument runs as follows. ${ }^{18}$ Let us rewrite equation (20) as $1+W G_{t}=W_{t}=\left[p_{t} B_{t} F_{2}^{q}\left(K_{t} ; B_{t}{ }_{t}{ }_{t} ; S_{t}\right)\right]$; where $S_{t}$ captures shift factors in the aggregate production function other than labor-augmenting technical progress. Then, the ..rst-degree homogeneity of the production function and the de..nition $\mathrm{I}_{\mathrm{t}}{ }^{\prime} \mathrm{B}_{\mathrm{t}} \mathrm{L}_{\mathrm{t}}=\mathrm{K}_{\mathrm{t}}$, imply that:

$$
1+W G_{t}=s_{L t} \frac{Y_{t}}{B_{t} L_{t} F_{2}^{o}\left(K_{t} ; B_{t} L_{t} ; S_{t}\right)}=s_{L t} \frac{f\left(I_{t} ; S_{t}\right)}{t_{t} f_{1}\left(t_{t} ; S_{t}\right)}
$$

where $\mathrm{f}_{\mathrm{t}}^{\prime}, \mathrm{B}_{\mathrm{t}} \mathrm{E}_{\mathrm{t}}=\mathrm{K}_{\mathrm{t}}$.

Recall now the multiplicative form we assumed for the labor share in equation (15): $S_{L t}=g\left(k_{t} ; S_{t}\right) h\left(X_{t}\right)$. M aking use of the identity between $g(k)$ and If $q()=f(I)$ given by equation (3), equation (21) boils down to:

$$
1+W G_{t}=h\left(X_{t}\right) \frac{f_{1}^{q}\left(I_{t} ; S_{t}\right)}{f_{1}\left(t_{t} ; S_{t}\right)}
$$

This equation tells us that the wage gap is the product of the component of the labor share which is ox the SK schedule, times the ratio between the marginal product of labor at current employment and at full employment. This ratio is the true wage gap; it tells us by how much wages would have to fall to eliminate unemployment, holding the production function and the $X_{t}$ variables constant. The ..rst term, on the other hand, captures a labor demand shift, which tells us that, given the unemployment rate, wages must fall if the gap between the shadow cost of labor and the wage increases.

Note that our empirical estimates allow us to recover $h\left(X_{t}\right)$, since we assumed in equation (17) that: $h\left(X_{t}\right)=\exp \left(\S_{k}{ }^{-}{ }_{k} x_{t}^{k}\right)$, where $X_{t}=\left(\$ \ln n_{t} ; z_{t} ; f^{f} c r_{t} ; V_{t}\right)$. Moreover, we can also approximate the second term, $f_{1}{ }_{1}\left(l_{t} ; S_{t}\right)={ }_{1}{ }_{1}\left(l_{t} ; S_{t}\right)$, so as to construct a series for the change in the wage gap and its components. We have:

$$
\begin{aligned}
& \pitchfork W G_{t} \quad 1 / 4 \nsubseteq \ln \left(1+W G_{t}\right) \\
& 1 / 4 \phi \operatorname{lnh}\left(X_{t}\right)+\phi \ln f_{1}^{O}\left(I_{t} ; S_{t}\right) ; \phi \ln f_{1}^{O}\left(f_{t} ; S_{t}\right)
\end{aligned}
$$

\footnotetext{
${ }^{18} \mathrm{In}$ this subsection we ignore the sector and country subindexes, as well as interactions with the rigidity and corporatism dummies, for simplicity.
} 
Noting that $f_{1}^{0}\left(l_{t} ; S_{t}\right)=g\left(k_{t} ; S_{t}\right)=\left(k_{t} l_{t}\right)$ and denoting $k_{t}=1=f\left(l_{t} ; S_{t}\right)$ this can be expressed as:

$$
\begin{aligned}
& \phi W G_{t} 1 / 4 \phi \ln _{3} h\left(X_{t}\right)+{ }^{3} \phi \ln g\left(k_{t} ; S_{t}\right) i \phi \ln g\left(k_{t} ; S_{t}\right) \\
& \text { i } \phi \ln k_{t} i \notin \ln k_{t} i \quad \phi \ln l_{t} i \notin \ln f_{t}
\end{aligned}
$$

Now, using equations (3) and (4), and neglecting second order terms in $u$ we have that $\ln k_{t} 1 / 4 \ln k_{t}$ i $g\left(k_{t} ; S_{t}\right) u_{t}$ and $\left.\phi \ln \right|_{t} 1 / 4 \phi \ln l_{t} i \quad u_{t}$ : If we further assume that $g$ is isoelastic in $\mathrm{k}$ and log-separable in $\mathrm{k}$ and $\mathrm{S}$; as in equation $(16), \mathrm{g}\left(\mathrm{k}_{\mathrm{t}} ; \mathrm{S}_{\mathrm{t}}\right)=$ $\mathrm{k}_{\mathrm{t}}^{\prime}{ }^{\circ}\left(\mathrm{S}_{\mathrm{t}}\right)=\mathrm{k}_{\mathrm{t}}{ }^{1}\left(\mathrm{q}_{\mathrm{t}}=\mathrm{p}_{\mathrm{t}}\right)^{-}{ }^{-}$, then the above equation can be rewritten as:

$$
\phi W G_{t} 1 / 4 \varnothing \ln h\left(X_{t}\right)+\left(\begin{array}{lll}
1 & i & 1
\end{array}\right) \phi\left(k_{t}^{\prime} \circ\left(S_{t}\right) u_{t}\right)+\pitchfork u_{t}
$$

or

$$
\begin{aligned}
\$ W G_{t} 1 / 4 & \$ \operatorname{lnh}\left(X_{t}\right)+\left(1 ; k_{t}^{\prime}{ }^{\circ}\left(S_{t}\right)\right) \notin u_{t} \\
& +\left({ }^{\prime} i 1\right) \notin\left(k_{t}^{\prime}{ }^{\circ}\left(S_{t}\right)\right) u_{t}+{ }^{\prime} k_{t}^{\prime}{ }^{\circ}\left(S_{t}\right) \notin u_{t}
\end{aligned}
$$

or, for use in the next subsection:

$$
\$ W G_{t} 1 / 4 \$ \ln h\left(X_{t}\right)+\left(1 ; k_{t}^{\prime}{ }^{\circ}\left(S_{t}\right)\left(1 ;{ }^{\prime}\right)\right) \$ u_{t}+\left(\begin{array}{lll}
{ }^{\prime} & i & 1
\end{array}\right) \notin\left(k_{t}^{\prime}{ }^{\circ}\left(S_{t}\right)\right) u_{t}
$$

The ..rst term in equation (22) is the contribution of the labor demand shift. If it is equal to, say, $-1 \%$, it means that labor demand has fallen, so that wages must fall by $1 \%$ to maintain unemployment constant. In other words, we are referring to labor demand shocks which increase the wedge between the wage and the shadow cost of labor, thus the measured wage gap falls, since the wage is below the true labor cost. We can further decompose this labor demand shift into an explained component (i.e., that explained by our explanatory variables, $\phi \mathrm{n}$, and $\mathrm{I}^{\mathrm{f}} \mathrm{c}$ ) and an unexplained one, which is the contribution of the residual. This residual may be interpreted as capturing changes in the price-cost markup, but it may also contain other shocks.

The change in the true wage gap is the sum of all other terms in equation (22). If it is equal to, say, $1 \%$, it means that wages would have to fall by $1 \%$ more in order to restore full employment. This may be due to the fact that unemployment has risen or to a change in the shape of the marginal product schedule. It can be further decomposed as follows. The second term, $\left(1 ; k_{t}^{\prime}\left(S_{t}\right)\right) \notin u_{t}$, is the contribution to the wage gap of changes in the discrepancy between the marginal product of labor at current employment and at full employment, holding the employment elasticity of output (i.e., $g(k ; S))$ constant. The last, composite term, $\left({ }^{\prime} ; 1\right) \$\left(k_{t}^{\prime}{ }^{\circ}\left(S_{t}\right)\right)$ 
$u_{t}+{ }^{\prime} k_{t}^{\prime}{ }^{\circ}\left(S_{t}\right) \notin u_{t}$, is the contribution of all changes in the employment elasticity of output, whether induced by shifts in the production function captured by the shift factor $\mathrm{S}$ or by the variation of that elasticity as $\mathrm{k}$ and $\mathrm{u}$ change.

Note that while the true wage gap may fall at times of rising unemployment (if the employment elasticity of the marginal product falls), its value is al ways positive if unemployment is positive. The reason is that if we start from zero unemployment, then the true wage gap must rise as $u_{t}$ rises, since $\left(1 ; k_{t}^{\prime}{ }^{\circ}\left(S_{t}\right)\left(1 ;{ }^{\prime}\right)\right)>0 .{ }^{19} \quad I n$ our empirical estimates, with the speci..cation of Table 4 , this expression takes an average value of 0.35 , being negative only for 60 observations ( $2 \%$ of the sample) in the agricultural sector. ${ }^{20}$

\subsection{The evolution of wage gaps in two countries}

We now show computed changes in the wage gaps for the US and (West) Germany, the only large economies for which there are data for all 14 industries over the full period. In our computation we use the estimates in section 3 , by considering each country as a basket of industries and applying the estimated coed cients to the particular industry con..guration in the country. We use the parameter estimates obtained from the speci..cation in column (4) of Table 5, which allow the coed cients on the variables in $X_{t}$ to vary depending on the country's degrees of labor market rigidity and corporatism. The results would be very similar if we alternatively used the parameters in column (5). Along with data on unemployment rates, those estimates then allow us to perform the decomposition in equation (23). I mplementing it with industry level data entails some problems, discussed in A ppendix A, which we solve by computing the aggregates in equation (23) as geometric averages, weighting industry-varying variables by their employment shares.

We should note from the outset that this procedure may only provide a rough approximation to wage gaps, since parameter estimates from the panel result from averaging underlying coec cients which may vary across countries, and since, moreover, the list of sectors available for estimation is not exhaustive.

Figure 6 depicts the part of wage gap levels explained by the regressors in both countries, calculated by accumulating changes since 1973, taken as the reference year $(=100)$. Figure 7 shows the decomposition described in equation (23) taking one term at a time (i.e. assuming changes in the other two terms were absent), also in index form. Figure 8 presents the contributions to the labor demand shifts of each of the relevant variables: $\$ \ln n_{t}, 3 / 4$, and $f^{f} r_{t}$. Lastly, the computed shifts

\footnotetext{
${ }^{19} N$ ote that $\left(1 ; k_{t}^{\prime}\left(S_{t}\right)\left(1 ;{ }^{\prime}\right)\right)=1 ; g\left(k_{t} ; S_{t}\right)+k_{t} g^{0}\left(k_{t} ; S_{t}\right), k_{t}=1=f\left(I_{t}\right)$, and $g\left(k_{t} ; S_{t}\right)=$ $I_{t} f q\left(I_{t}\right)=f\left(I_{t}\right)$. Thus, $g^{q}\left(k_{t} ; S_{t}\right)=I_{t} f q\left(I_{t}\right)$ i $\left(f q\left(I_{t}\right)+I_{t} f{ }^{\infty}\left(I_{t}\right)\right)\left(f\left(I_{t}\right)=f\left(I_{t}\right)\right)$, so that $k_{t} g_{t}^{0}\left(k_{t} ; S_{t}\right)=$

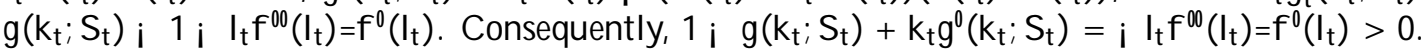

${ }^{20} \mathrm{~T}$ he same is true for the estimates in column (4) of Table 5 , used in the next subsection.
} 
and their components are provided in Table A5, which also contains the evolution of wage gaps inclusive of the contribution of the unexplained residuals.

Figure 6 indicates increases in wage gaps in both Germany and the US in the mid-1970s and early-1980s, but in Germany the increases are larger and tend to disappear more slowly. Moreover, Germany suxers a post-reuni..cation surge in the wage gap which is absent in the US.

Figure 7 suggests that the marginal product of labor in Germany is around $2 \%$ higher, holding capital constant, than what it would be if unemployment was at its 1973 level. The equivalent ..gure for the US, where unemployment has also risen but by less, is below one percent. The ..gure al so reveals that in both countries there are large shifts in labor demand that axect the measured wage gap. In Germany these movements are countercyclical and Figure 8 shows that they are chieły explained by the contribution of adjustment costs: in recessions the shadow cost of labor goes down relative to the wage, labor demand is thus high -meaning higher than absent adjustment costs- and so is the measured wage gap, as in recessions adjustment costs drive a positive wedge between the wage and the marginal product of labor. Other components, such as changes in union power or uncertainty, play virtually no role in Germany. In the United States, the labor demand component is more erratic and less persistent. It is also chieły driven by adjustment costs, but a continuing decline in union power has also contributed to bringing down wages relative to the marginal product of labor. Contrary to the conventional wisdom, there is virtually no contribution to the wage gap, in either country, by factors that change the shape of the production function, e.g. changes in the capital-output ratio -driven by labor-augmenting technical progress or movements in factor costs such as wages and interest rates- or in the real price of oil.

Recently Blanchard $(1997,1998)$ and Caballero and Hammour (1998) have sought to explain the dixerent evolution of unemployment in continental European and Anglo-Saxon countries since the 1970s, bearing in mind the evolution of the labor share. Blanchard (1997) explains such evolution, in continental Europe, as resulting from responses to labor supply shifts in the 1970s (oil shocks, the productivity growth slowdown, changes in labor institutions) and labor demand shocks in the 1980s. His attempt at distinguishing between shifts in the distribution of rents and biased technological change as sources of the latter is however inconclusive. Our results support the idea that the European unemployment experience cannot be understood without recourse to signi..cant labor demand shifts. While they are not readily comparable to his, since we follow a dixerent approach, there are some similarities. First, Blanchard (1997) computes much higher labor demand shifts for Germany than for the US (Germany: -6\% over 1970-81, 3\% over 1981-95; US: $-3 \%$ and $0 \%$, respectively), in accordance with our own estimates. Second, Blanchard (1998) reports computations of yearly labor demand shifts only for France, which moreover vary depending on two exogenously chosen parameters: the degree 
of wage inertia and the elasticity of substitution of a CES production function. Nevertheless, a common theme is that computed labor demand shifts for France tend to be negative in the mid-1970s, positive in the ..rst half of the 1980s, and negative again in the second half of the 1980s, while our results for Germany follow a similar pattern (cfr. his Figure 11 with our Table A4). ${ }^{21}$

As the ..gures in Table A 4 make clear, however, the evolutions commented so far are dwarfed by the contribution of the residual, i.e. the unexplained component in the gap between wages and marginal product. In the case of Germany, this unexplained component accounts for most of the hump-shaped pattern of the labor share in the 1970s and 1980s. This result casts doubts over the interpretation of that stylized fact suggested by Caballero and Hammour (1998). A ccording to these authors, the hump shape is due to the lagged response of capital-labor substitution to initial wage pushes. That is, wage pushes increase the labor share in the short run because of sluggishness in labor demand adjustment (due to institutions which raise labor's capability of appropriating rents, such as ...ring costs, unemployment bene..ts, and social security contributions; and to increases in speci..city). These pushes, however, reduce the labor share in the long run, as substitution of capital for labor works its way. Such pattern is consistent with a negatively sloped SK curve, and the exect of adjustment costs that we have found. But the contributions of $\phi \mathrm{n}$ and $\mathrm{k}$ actually fail to pick up the hump-shaped pattern for the labor share, which is mostly driven by the residual. This suggests that we have to look for other explanations.

An interesting ..nding is that the residual in the US exhibits the same humpshaped pattern as in Germany, despite the fact that the total labor share does not exhibit this behavior. Thus it seems that our empirical procedure allows us to recover some labor demand shock common to the two countries, which was not apparent in the raw data. At this stage, we can only speculate about the nature of that demand shock. The obvious interpretation in terms of markups seems implausible; only further research can uncover the factors underlying this similar evolution of the residuals in Germany and the US.

\section{Conclusions}

In this paper we show that movements in the labor share can be fruitfully decomposed into movements along a technology-determined curve -the share-capital (SK ) schedule-, shifts of this locus, and deviations from it. Movements along the SK curve capture changes in factor prices such as wage pushes and changes in real interest rates, as well as the contribution of labor-augmenting technical progress.

\footnotetext{
${ }^{21}$ For G ermany, Blanchard (1997) simply reports a labor demand shift of $-6 \%$ over $1970-81$ and of $3 \%$ over 1981-95.
} 
The curve is itself shifted by factors such as non-labor embodied technical progress or changes in the price of imported materials. Lastly, other sources of variation of the labor share are represented by movements ox the SK curve, and are accounted for by deviations from marginal cost pricing such as changes in markups, labor adjustment costs, and changes in workers' bargaining power.

We analyze the performance of the model empirically, using data on a panel of 14 industries in 14 OECD countries, over the period 1973-93, by estimating the relationship between the labor share and the capital-output ratio, controlling for variables intended to capture some of the factors mentioned above. In the estimation we follow a recent proposal by Arellano and Bover (1995) of a system estimator for panel data, i.e. a generalized method of moments estimator with instrumental variables which exploits the information contained in the relationship between the variables in both levels and ..rst dixerences.

We ..nd a signi..cant relationship between the two key variables, i.e. favorable evidence for the SK schedule. There is also evidence of movements in the labor share due to either shifts of the SK schedule, arising from changes in the real price of oil, and of movements ox such schedule, arising from labor adjustment costs and changes in workers' bargaining power.

We then employ the empirical estimates in trying to shed light on the sources of European unemployment, through the concept of wage gaps, i.e. the dixerence between wages and the marginal product of labor. We compute wage gaps in two large economies, the US and Germany and decompose its evolution according to the theoretical model. Our results indicate that there are sizable labor demand shifts in both countries, especially in Germany, where they essentially arise from the presence of labor adjustment costs. 


\section{A ppendix A \\ A Igebraic derivations}

A.1 R elationship between the labor share and the skill premium (section 2.3.2)

To show how labor heterogeneity axects the SK relationship, we follow K rusell et al. (1997) and consider the special case where the production function is:

$$
Y=\left(\left(A K+B_{1} L_{1}\right)^{\prime \prime}+\left(B_{2} L_{2}\right)^{\prime \prime}\right)^{1=}
$$

Intuitively, this production function means that tasks can be done either by capital or unskilled labor, but that skilled labor is needed to monitor tasks. We can show that there is now a relationship between the labor share, the capital-output ratio, and the premium of skilled over unskilled labor. To do so, note that wages must be equal to:

$$
\begin{gathered}
w_{2}=\left(\left(A K+B_{1} L_{1}\right)^{\prime \prime}+\left(B_{2} L_{2}\right)^{\prime \prime}\right)^{1=}{ }^{\prime} i B_{2} L_{2} L_{2}{ }^{1} \\
W_{1}=\left(\left(A K+B_{1} L_{1}\right)^{\prime \prime}+\left(B_{2} L_{2}\right)^{\prime \prime}\right)^{1=}{ }^{1} i{ }^{1}\left(A K+B_{1} L_{1}\right)^{\prime \prime}{ }^{1} B_{1}
\end{gathered}
$$

implying that the labor share is equal to:

$$
S_{L}=\frac{B_{1} L_{1}\left(A K+B_{1} L_{1}\right)^{\prime \prime}{ }^{1}+\left(B_{2} L_{2}\right)^{\prime \prime}}{\left(A K+B_{1} L_{1}\right)^{\prime}+\left(B_{2} L_{2}\right)^{\prime}}
$$

and the wage premium, ! ' $\mathrm{w}_{2}=\mathrm{w}_{1}$, to:

$$
!=\frac{B_{2}\left(B_{2} L_{2}\right)^{n_{i} 1}}{B_{1}\left(A K+B_{1} L_{1}\right)^{i_{11}}}
$$

This equation can be inverted as:

$$
A K+B_{1} L_{1}=B_{2} L_{2} \tilde{A}(!)
$$

where $\tilde{A}(!)=\left(B_{1} !=B_{2}\right)^{\frac{1}{1 i^{*}}}$.

We can also compute the capital-output ratio, writing:

$$
(\mathrm{Ak})^{\prime \prime}=\frac{(\mathrm{AK})^{\prime \prime}}{\left(\mathrm{B}_{2} \mathrm{~L}_{2}\right)^{\prime \prime}(1+\tilde{A}(!))^{m}}
$$

which implies: 


$$
A K=A k B_{2} L_{2}(1+\tilde{A}(!) ")^{1=\prime}
$$

Substituting this equation into the previous one, we may express $B_{1} L_{1}$ as a function of $B_{2} L_{2}$ and !, which we may then substitute, alongside with the latter two equations, into equation (A 1.1) to get:

$$
\left.S_{L}=1 \text { i } \operatorname{AkÃ}(!)^{\prime \prime} i{ }^{1}(1+\tilde{A}(!))^{\prime \prime}\right)^{1\lrcorner} i 1
$$

A.2 The labor share with labor adjustment costs (section 2.4.3)

We wish to show that the labor share is a decreasing function of the change in employment when adjustment costs are part of the labor share. In this case we have:

$$
\begin{aligned}
S_{L} & =\frac{w L+A C(\phi L)}{F(K ; B L)}=\frac{B f q() L ; A C q \phi L) L+A C(\phi L)}{F(K ; B L)} \\
& =g(K)+\frac{A C(\$ L) ; A C q \phi L)\left(L_{i 1}+\phi L\right)}{F\left(K ; B\left(L_{i 1}+\phi L\right)\right)}
\end{aligned}
$$

The last term's derivative with respect to $\phi L$ has the same sign as its numerator: i $A C^{q}(\phi L) F(K ; B L) L$; $[A C(\$ L)$; $\left.A C q \& L) L\right] B f q()$. This is clearly negative if $\$ L \cdot 0$ : Assume, to the contrary, that $\phi L>0$. Then this term is negative if and only if

$$
A C q(L)>i \frac{A C(\phi L)}{L^{2}} \frac{I f(I)}{f(I)}+\frac{A C q(L)}{L} \frac{I f(I)}{f(I)}
$$

A suф cient condition for that to hold is $\left.\left.A C \mathbb{Q}_{(} \phi L\right) L=A C q \phi L\right)>$ If $q()=f(I)$ : For $A C(\$ L)$ quadratic in $\phi L$ this is equivalent to $L=\$ L>g(k)$; which is extremely plausible as $g(k)<1$ and $\$ L$ is likely to be smaller than $L$.

\section{A.3 Computing the wage gap from industry estimates (section 4.2)}

The de..nition of a wage gap concept at the industry level is full of conceptual problems. In addition to the fuzzyness of the concept of industry unemployment, industry rents may generate discrepancies between the marginal product of labor in one industry and its value elsewhere in the economy, thus contributing to a positive wage gap in that industry regardless of the degree of slackness in the labor market. We have dealt with this issue by computing the aggregates in equation (22) as geometric averages, weighting industry-varying variables by their employment shares. 
Recalling the notation in equation (18), the precise empirical implementation of equation (22) is as follows (suppressing country subindex $\mathrm{j}$ for clarity):

$$
\begin{aligned}
\phi W G_{t} 1 / 4 & \phi \operatorname{lnh}\left(X_{t}\right)+{ }^{\mu}{ }^{\mu} k_{t}^{b_{1 t}}\left(q_{t}=p_{t}\right)^{b_{2 t}}\left(1 ; \quad b_{1 t}\right)^{q} \phi u_{t} \\
& +\left(b_{1 t} i \quad 1\right) \notin k_{t}^{b_{1 t}}\left(q_{t}=p_{t}\right)^{b_{2 t}} u_{t}^{q}
\end{aligned}
$$

where: $k_{t}=\exp \left({ }^{P}{ }_{i} e_{i t} \ln k_{i t}\right), q_{t}=p_{t}=\exp \left(\ln \left(q_{t}=p_{t}\right)\right),{ }_{r t}={ }^{P}{ }_{i} e_{i t} b^{b}$ rit $\underset{\mu}{\text { for } r} r=1 ; \tau_{i}$, $e_{i t}=N_{i t}={ }_{i}{ }_{i} N_{i t}$ with $N$ denoting employment, $\ln h\left(X_{t}\right)={ }^{P}{ }_{i} e_{i t}{ }_{k=3}{ }_{k}{ }_{k} x_{i t}^{k}$, $X_{i t}=\left(\phi \ln n_{i t} ; z_{4 t} ; f^{f} c_{t} ; \phi_{t}\right)$, the symbol $b$ denotes estimates, and $i=1 ; \ldots ; 14$. Note that ${ }_{r t}$ for $r=3 ; \cdots ; 5$, dixer across countries, due to the interactions with the labor market rigidity and corporatism dummies. 


\section{A ppendix $B$ Data sources and de..nitions of variables}

The variables we use in the econometric estimation are constructed from the OECD International Sectoral Data Base (ISDB) 1996, documented in OECD (1996). It covers the period 1960-95, but disaggregated data on a suc cient scale for most variables are available for 1970-93. The variables we use are as follows (original ISD B variables denoted by their own acronyms in capital letters):

Labor share: $S_{L}=1 ;$ OP:

Capital-output ratio: $k=K T V D=G D P D$ :

Real oil price: $q=p=$ Nominal oil price/ GDP de ator $=(P O f E R)=(G D P=G D P V)$ : Labor con $¥$ ict rate: Icr $=$ Number of labor con $¥$ icts (strikes+lock-outs) / Number of employees in the preceding year (Source: CEP-OECD Data Set, documented in Bell and Dryden 1996).

Adjusted labor share: $S_{L}^{\alpha}=$ WSSS $(E T=E E)=(G D P(1 ; \quad I N D))$

where:

${ }^{2} \mathrm{OP}=\mathrm{R}$ atio of gross operating surplus to value added minus net indirect taxes.

2 K TV D = Gross capital stock, at 1990 prices and 1990 PPPs (US dollars).

2 GDPD = Value added at market prices, at 1990 prices and 1990 PPPs. (US dollars).

2 P O = Price of oil in dollars (Source: International M onetary Fund, International Financial Statistics, IFS).

${ }^{2} \mathrm{ER}=\mathrm{Exchange}$ rate vis-à-vis the dollar ( $M$ arket rate/ $\mathrm{Par}$ or Central rate, period average. Source: IFS).

${ }^{2} \mathrm{GDP}=$ Value added at market prices, current prices, national currency.

2 GDPV $=$ Value added at market prices, at 1990 prices, national currency.

2 WSSS $=$ Compensation of employees, at current prices, national currency.

$2 \mathrm{EE}=$ Number of employees.

$2 \mathrm{ET}=$ Total employment.

2 IND = Ratio of net indirect taxes to value added.

The sectoral breakdown used distinguishes between 14 industries. The number of observations available for the econometric estimation by country, year, and industry are in Table A 1. 
TABLE A 1

Number of Observat ions Avail abl e for Economet $r$ ic Est imat ion

By Count ry, Y ear, and Indust ry

\begin{tabular}{|c|c|c|c|c|c|}
\hline Country & No. & Year & No. & Year & No. \\
\hline United States & 294 & 1973 & 69 & 1987 & 165 \\
\hline Canada & 256 & 1974 & 119 & 1988 & 165 \\
\hline J apan & 224 & 1975 & 119 & 1989 & 163 \\
\hline Germany & 294 & 1976 & 119 & 1990 & 163 \\
\hline France & 168 & 1977 & 125 & 1991 & 163 \\
\hline Italy & 214 & 1978 & 145 & 1992 & 132 \\
\hline United K ingdom & 121 & 1979 & 145 & 1993 & 84 \\
\hline A ustralia & 102 & 1980 & 163 & & \\
\hline Netherlands & 62 & 1981 & 163 & & \\
\hline B elgium & 239 & 1982 & 163 & & \\
\hline Denmark & 247 & 1983 & 163 & & \\
\hline Norway & 247 & 1984 & 164 & & \\
\hline Sweden & 260 & 1985 & 165 & & \\
\hline Finland & 294 & 1986 & 165 & & \\
\hline Industry & & & & ISIC code & No. \\
\hline \multicolumn{4}{|c|}{ A griculture, hunting, forestry and ..shing } & 1 & 260 \\
\hline \multicolumn{4}{|c|}{ M ining and quarrying } & 2 & 200 \\
\hline \multicolumn{4}{|c|}{ Food, beverages and tobacco } & 31 & 207 \\
\hline \multicolumn{4}{|c|}{ Textiles, wearing apparel and leather products } & 32 & 207 \\
\hline \multicolumn{4}{|c|}{ Paper, paper products, printing and publishing } & 34 & 198 \\
\hline \multicolumn{4}{|c|}{ Chemicals, petroleum, coal, rubber and plastic } & 35 & 203 \\
\hline \multicolumn{4}{|c|}{ Non-met. mineral products excl. petrol. and coal } & 36 & 188 \\
\hline \multicolumn{4}{|c|}{ Basic metal industries } & 37 & 187 \\
\hline \multicolumn{4}{|c|}{ Fabricated metal prods., machinery and equipment } & 38 & 207 \\
\hline \multicolumn{4}{|c|}{ Electricity, gas and water } & 4 & 257 \\
\hline \multicolumn{4}{|l|}{ Construction } & 5 & 257 \\
\hline \multicolumn{4}{|c|}{ W holesale and retail trade } & $61+62$ & 191 \\
\hline \multicolumn{4}{|c|}{ Transport, storage and communications } & 7 & 239 \\
\hline \multicolumn{4}{|c|}{ Community, social and personal services } & 9 & 221 \\
\hline
\end{tabular}

Not e.- Missing industries: Wood and wood products (32); Restaurants and hotels (63); and Finance, insurance, real estate and business services (8), Producers of government services (-). 


\section{A ppendix C A dditional empirical results}

TABLE A2

Descript ive Stat ist ics of the Main Variabl es in the Adjust ed Labor Share Sampl e

(All observations in the sample; 1973-93)

\begin{tabular}{lrrrr}
\hline \hline & Mean & $\begin{array}{l}\text { Standard } \\
\text { deviation }\end{array}$ & Minimum & Maximum \\
\hline Adjusted labor share & 63.1 & 17.0 & 2.4 & 99.5 \\
Capital-output ratio & 3.7 & 4.2 & 0.4 & 49.1 \\
Real price of oil & 30.8 & 16.5 & 5.7 & 96.2 \\
Employment growth rate & -0.5 & 4.2 & -22.3 & 14.9 \\
Output volatility & 2.2 & 1.7 & 0.2 & 32.4 \\
Labor conłict rate & 0.9 & 1.2 & 0.0 & 6.5 \\
\hline
\end{tabular}

Not e.- All variables in percentages, except the capital-output ratio and the real price of oil. The data correspond to an unbalanced panel of 14 industries and 14 countries. Total number of observations: 2330. Source: OECD International Sectoral Data Base (ISDB). 
TABLE A3

Est imat ion of Adjust ed Labor Share Equation

Dependent variable: $\ln s_{\mathrm{L} ; i j \mathrm{t}}^{\natural}$

\begin{tabular}{|c|c|c|c|c|}
\hline & $\begin{array}{c}\text { Capital- } \\
\text { output } \\
\text { ratio } \\
\ln \mathrm{k}_{\mathrm{ijt}} \\
\end{array}$ & t-ratio & $\begin{array}{c}\text { Real oil } \\
\text { price } \\
\ln \left(\mathrm{q}_{\mathrm{jt}}=\mathrm{p}_{\mathrm{jt}}\right)\end{array}$ & t-ratio \\
\hline \multicolumn{5}{|l|}{ Industry: } \\
\hline A griculture & 0.16 & $(0.03)$ & -0.11 & $(0.40)$ \\
\hline Mining & -0.56 & (1.30) & -0.09 & $(0.15)$ \\
\hline Food & -0.03 & $(0.23)$ & -0.03 & $(0.13)$ \\
\hline Textiles & 0.03 & $(0.03)$ & 0.02 & $(0.45)$ \\
\hline Paper & 0.05 & $(0.22)$ & -0.00 & $(0.19)$ \\
\hline Chemicals & 0.32 & $(0.76)$ & -0.15 & $(0.66)$ \\
\hline Non-metallic minerals & 0.25 & $(0.70)$ & -0.08 & $(0.29)$ \\
\hline Basic metal & 1.06 & (3.31) & -0.52 & (3.48) \\
\hline Machinery & 0.01 & $(0.02)$ & 0.02 & $(0.44)$ \\
\hline Electricity, Gas \& Water & -0.76 & (1.77) & 0.29 & (1.48) \\
\hline Construction & -0.46 & (1.33) & -0.03 & $(0.05)$ \\
\hline Trade & 0.24 & $(0.60)$ & 0.01 & $(0.33)$ \\
\hline Transport \& Communications & -0.04 & $(0.12)$ & 0.01 & $(0.34)$ \\
\hline Social services & -0.15 & $(0.48)$ & -0.02 & $(0.17)$ \\
\hline J oint signi..cance $(p)$ : & 109.56 & $(0.00)$ & 140.44 & $(0.00)$ \\
\hline Constant & -0.38 & (4.44) & & \\
\hline Employment change $\left(\$ \ln n_{i j t}\right)$ & -0.64 & $(5.02)$ & & \\
\hline Output volatility ( $\left.w_{\mathrm{jt} t}\right)$ & -0.16 & (1.23) & & \\
\hline Labor con $\neq i c t$ rate $\left(f^{f} c_{j t}\right)$ & -1.57 & $(2.20)$ & & \\
\hline Sargan: $p$ and d.f. & 0.50 & (61) & & \\
\hline Dix. Sargan: $p$ and d.f. & 0.18 & (45) & & \\
\hline $\mathrm{m}_{2}$ & -0.86 & & & \\
\hline
\end{tabular}

Not e.- No. of observations: 2330 , no. of industry-country units: 132 . Method: Instrumental variables, system estimator. Other information as in note to Table 4. 
TABLE A4

Variant s of Adjust ed Labor Share Equation

Dependent variable: In $\mathrm{S}_{\mathrm{L} ; \mathrm{ijt}}^{\mathrm{a}}$

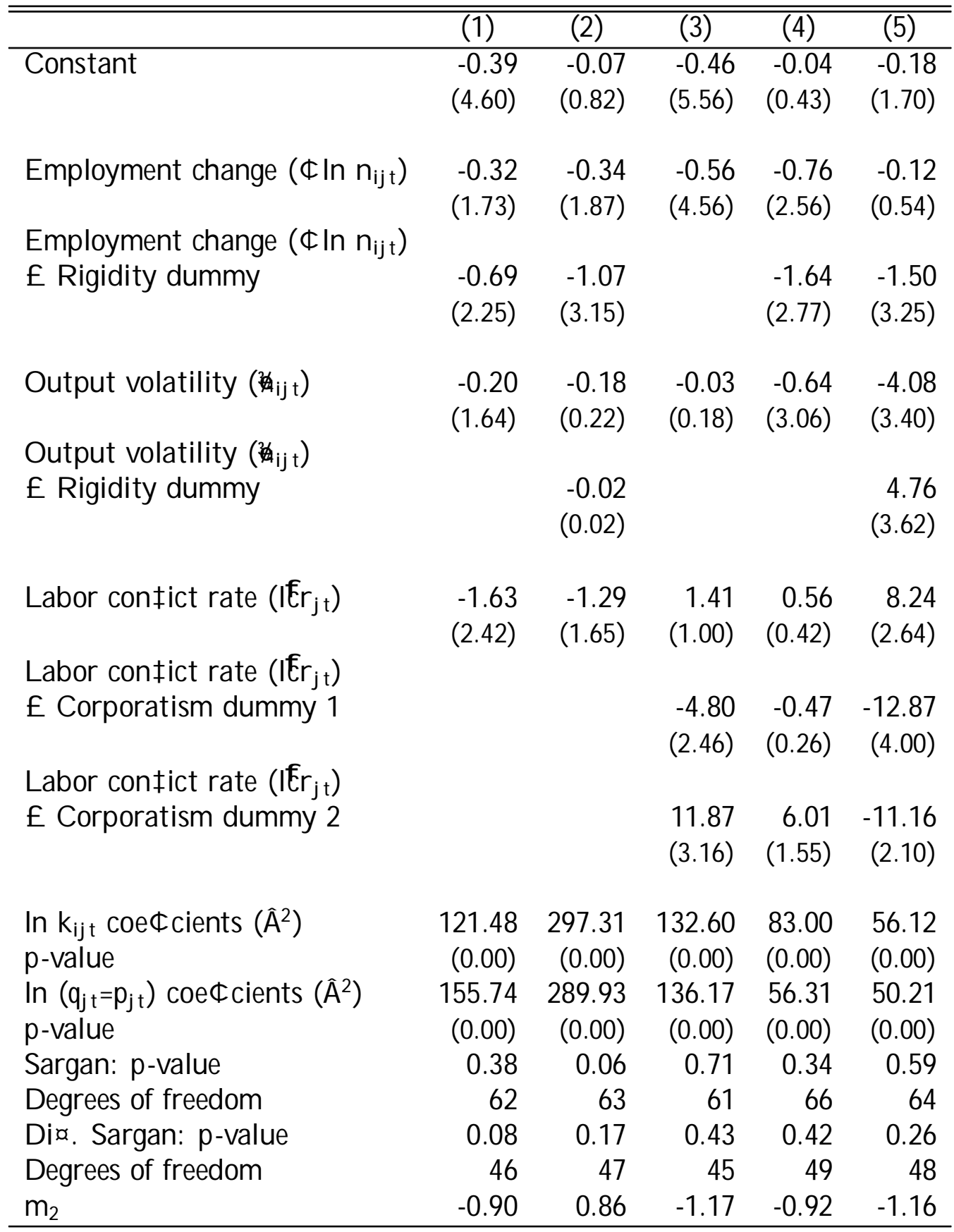

Not e.- No. of observations: 2330, no. of industry-country units: 132. Method: Instrumental variables, system estimator. Other information as in note to Table 4. 
TABLE A5

Decomposition of changes in the Wage Gap (\%)

A. Unit ed States

\begin{tabular}{|c|c|c|c|c|c|c|c|c|c|}
\hline Year & $\underset{(1)}{\ln n_{t}}$ & $\begin{array}{l}/ 4 \\
\text { (2) }\end{array}$ & $\begin{array}{l}\bar{l}^{f} \mathrm{rr}_{t} \\
\text { (3) }\end{array}$ & $\begin{array}{c}\ln h(:) \\
(4)\end{array}$ & $\begin{array}{l}g(:) \\
(5)\end{array}$ & $\begin{array}{l}u_{t} \\
(6)\end{array}$ & $\begin{array}{c}d G_{t} \\
(7)\end{array}$ & $\begin{array}{l}V_{t} \\
(8)\end{array}$ & $\begin{array}{c}W G_{t} \\
(9)\end{array}$ \\
\hline 1974 & 1.20 & -0.15 & -0.04 & 1.01 & 0.58 & 0.37 & 1.96 & 19.61 & 21.57 \\
\hline 1975 & 1.42 & -0.02 & -0.17 & 1.23 & -0.15 & 1.35 & 2.44 & -8.71 & -6.27 \\
\hline 1976 & -2.17 & -0.06 & -0.09 & -2.32 & 0.04 & -0.37 & -2.65 & 4.14 & 1.49 \\
\hline 1977 & -0.09 & 0.03 & 0.01 & -0.05 & 0.03 & -0.32 & -0.34 & 0.81 & 0.47 \\
\hline 1978 & -0.47 & 0.03 & -0.12 & -0.56 & -0.03 & -0.48 & -1.07 & 0.44 & -0.62 \\
\hline 1979 & 0.59 & 0.11 & -0.20 & 0.51 & 0.33 & -0.11 & 0.73 & 11.84 & 12.57 \\
\hline 1980 & 1.32 & -0.02 & -0.06 & 1.23 & 0.01 & 0.72 & 1.96 & 0.96 & 2.92 \\
\hline 1981 & -0.55 & -0.01 & -0.10 & -0.65 & -0.08 & 0.24 & -0.49 & -3.18 & -3.67 \\
\hline 1982 & 1.17 & 0.04 & -0.18 & 1.02 & -0.14 & 1.09 & 1.97 & -3.61 & -1.64 \\
\hline 1983 & -1.01 & 0.03 & -0.12 & -1.09 & -0.13 & -0.07 & -1.29 & -1.62 & -2.91 \\
\hline 1984 & -1.56 & -0.22 & -0.14 & -1.92 & 0.01 & -1.05 & -2.96 & -0.87 & -3.83 \\
\hline 1985 & 1.02 & 0.18 & -0.11 & 1.09 & -0.04 & -0.16 & 0.90 & -3.35 & -2.45 \\
\hline 1986 & 0.34 & 0.03 & -0.06 & 0.31 & -0.43 & -0.09 & -0.21 & -11.46 & -11.67 \\
\hline 1987 & -0.40 & -0.03 & -0.04 & -0.46 & 0.12 & -0.38 & -0.72 & 3.21 & 2.50 \\
\hline 1988 & -0.16 & 0.03 & -0.04 & -0.17 & -0.13 & -0.30 & -0.60 & -3.87 & -4.47 \\
\hline 1989 & 0.13 & 0.11 & -0.01 & 0.22 & 0.07 & -0.11 & 0.19 & 1.67 & 1.86 \\
\hline 1990 & 0.64 & 0.01 & -0.01 & 0.63 & 0.09 & 0.12 & 0.84 & 2.72 & 3.56 \\
\hline 1991 & 0.62 & 0.05 & -0.02 & 0.65 & -0.11 & 0.55 & 1.09 & -4.12 & -3.03 \\
\hline 1992 & -0.47 & 0.09 & -0.01 & -0.39 & -0.06 & 0.29 & -0.16 & -1.47 & -1.63 \\
\hline 1993 & -0.55 & 0.01 & -0.00 & -0.54 & -0.11 & -0.25 & -0.90 & -2.51 & -3.41 \\
\hline
\end{tabular}

Not e: See legenda at the bottom of panel B. 


\section{B. Ger many}

\begin{tabular}{|c|c|c|c|c|c|c|c|c|c|}
\hline Year & $\begin{array}{l}\phi \ln n_{t} \\
\text { (1) }\end{array}$ & $\begin{array}{l}3 / 4 \\
(2)\end{array}$ & $\begin{array}{l}I^{t} c r_{t} \\
\text { (3) }\end{array}$ & $\begin{array}{c}\ln \mathrm{h}(:) \\
\text { (4) }\end{array}$ & $\begin{array}{l}g(:) \\
(5)\end{array}$ & $\begin{array}{c}u_{t} \\
(6)\end{array}$ & $\begin{array}{l}V^{1} G_{t} \\
\text { (7) }\end{array}$ & $\begin{array}{l}v_{t} \\
(8)\end{array}$ & $\begin{array}{l}W G_{t} \\
(9)\end{array}$ \\
\hline 1974 & 4.36 & 0.05 & 0.02 & 4.43 & 0.26 & 0.53 & 5.23 & 18.23 & 23.45 \\
\hline 1975 & 3.38 & -0.11 & 0.13 & 3.40 & -0.06 & 0.83 & 4.16 & -6.76 & -2.60 \\
\hline 1976 & -5.22 & -0.07 & 0.01 & -5.28 & 0.04 & -0.01 & -5.25 & 5.40 & 0.15 \\
\hline 1977 & -1.40 & 0.02 & -0.01 & -1.39 & 0.02 & -0.05 & -1.43 & 2.88 & 1.45 \\
\hline 1978 & -0.39 & 0.08 & -0.03 & -0.35 & -0.01 & -0.07 & -0.43 & -1.03 & -1.47 \\
\hline 1979 & -1.98 & 0.01 & -0.05 & -2.01 & 0.23 & -0.25 & -2.03 & 17.14 & 15.11 \\
\hline 1980 & 0.41 & 0.18 & -0.01 & 0.58 & 0.03 & -0.00 & 0.61 & 4.53 & 5.14 \\
\hline 1981 & 3.46 & 0.02 & 0.00 & 3.49 & -0.04 & 0.70 & 4.14 & -4.83 & -0.69 \\
\hline 1982 & 2.27 & -0.09 & 0.04 & 2.23 & -0.09 & 1.00 & 3.13 & -6.35 & -3.22 \\
\hline 1983 & 0.59 & 0.00 & 0.03 & 0.62 & -0.10 & 0.74 & 1.27 & -6.14 & -4.87 \\
\hline 1984 & -3.60 & 0.08 & 0.05 & -3.47 & -0.01 & 0.01 & -3.48 & 2.60 & -0.88 \\
\hline 1985 & -1.02 & -0.08 & -0.03 & -1.12 & -0.04 & 0.03 & -1.13 & -0.60 & -1.73 \\
\hline 1986 & -1.11 & -0.00 & -0.02 & -1.14 & -0.51 & -0.15 & -1.79 & -12.31 & -14.11 \\
\hline 1987 & 0.99 & 0.10 & -0.01 & 1.07 & 0.16 & -0.02 & 1.22 & 3.37 & 4.58 \\
\hline 1988 & -0.15 & -0.01 & -0.03 & -0.18 & -0.18 & -0.01 & -0.37 & -5.49 & -5.85 \\
\hline 1989 & -1.37 & -0.01 & -0.01 & -1.38 & 0.13 & -0.33 & -1.58 & 3.95 & 2.37 \\
\hline 1990 & -2.94 & -0.02 & 0.02 & -2.94 & 0.15 & -0.31 & -3.11 & 5.62 & 2.51 \\
\hline 1991 & 0.88 & -0.01 & 0.01 & 0.89 & -0.11 & 0.20 & 0.98 & -3.15 & -2.16 \\
\hline 1992 & 3.59 & -0.05 & 0.01 & 3.54 & -0.11 & 0.45 & 3.88 & -5.15 & -1.27 \\
\hline 1993 & 5.13 & -0.29 & 0.02 & 4.86 & -0.22 & 0.49 & 5.13 & -7.51 & -2.37 \\
\hline
\end{tabular}

Legenda for Tabl e A4 (cfr. equation (22) and A ppendix A.3):

(1) Contribution of changes in the employment growth rate.

(2) Contribution of changes in output volatility.

(3) Contribution of changes in the labor conłict rate.

(4) Contribution of labor demand shifts $(=(1)+(2)+(3)): \$ \operatorname{lnh}\left(X_{t}\right)$.

(5) Contribution of changes in $g\left(k_{t} ; S_{t}\right):\left({ }^{\prime} i \quad 1\right) \phi\left(k_{t}^{\prime}{ }^{\circ}\left(S_{t}\right)\right) u_{t}$.

(6) Contribution of changes in unemployment: $\left(1 ; k_{t}^{\prime}{ }^{\circ}\left(S_{t}\right)\left(1 ;{ }^{\prime}\right)\right) \$ u_{t}$.

(7) Changes in explained wage gap: (4)+(5)+(6).

(8) Contribution of changes in the residual.

(7) Changes in total wage gap: (7)+(8). 


\section{Ref er ences}

A rellano, M. and S. Bond (1991), "Some Tests of Speci..cation for Panel Data: Monte Carlo Evidence and an Application to Employment Equations", Review of Economic Studies 58, 277-297.

A rellano, M . and S. B ond (1998), "Dynamic Panel Data Estimation using DPD98 for GAUSS", mimeo, CEMFI.

A rellano, M. and O. Bover (1997), "A nother Look at the Instrumental-Variable Estimation of Error-Components Models", J ournal of Econometrics 68, 2952.

Artus, J . (1984), "The Disequilibrium Real Wage Hypothesis: An Empirical Evaluation", I MF Stax Papers 31, 249-302.

Bean, Ch. (1994), "European Unemployment: A Survey", J ournal of E conomic Literature 32, 573-619.

Bell, B. and N. Dryden (1996), "The CE P-OECD Data Set (1950-1992)", mimeo, Centre for Economic Performance, London School of Economics.

Bénabou, R. (1992), "Inłation and Markups: Theories and Evidence from the Retail Trade Sector", European E conomic Review 36, 566-574.

Bentolila, S. and G. Bertola (1990), "Firing Costs and Labour Demand: How Bad is Eurosclerosis?", Review of Economic Studies 57, 381-402.

Blanchard, O. (1997), "The Medium Run", Brookings Papers on Economic Activity, 2, 89-158.

Blanchard, O. (1998), "Revisiting European Unemployment: Unemployment, Capital Accumulation and Factor Prices", NBER Working Paper no. 6566.

Blanchard, O. and S. Fischer (1989), Lectures on Macroeconomics, Cambridge, Mass., The MIT Press.

Blundell, R. and S. B ond (1997), "Initial Conditions and Moment Restrictions in Dynamic Panel Data Models", mimeo, Institute of Fiscal Studies (forthcoming in J ournal of E conometrics).

Bruno, M. and J . Sachs (1985), E conomics of Worldwide Stagłation, Cambridge, Mass., Harvard University Press. 
Caballero, R. and M. Hammour (1997), "J obless Growth: A ppropiability, Factor Substitution, and Unemployment", Carnegie-Rochester Conference on Public Policy 48, 51-94.

Calmfors, L. and J . Driф II (1988), "Centralisation of Wage B argaining and M acroeconomic Performance, Economic Policy, 6, 13-61.

Goodwin, R. (1967), "A Growth Cycle", in C. Feinstein (ed.), Socialism, Capitalism and Economic Growth. Essays P resented to Maurice Dobb, Cambridge, Cambridge University Press.

Hamermesh, D. (1993), Labor Demand, Princeton, New J ersey, Princeton University Press.

Hall, R. (1990), "Invariance Properties of Solow's Productivity Residual", in P. Diamond and O. Blanchard, eds, Growth / Productivity / Unemployment: Essays to Celebrate B ob Solow's Birthday, Cambridge, Mass., The M IT P ress.

Krusell, P., L. Ohanian, J . Ríos-Rull and G. Violante (1997), "Capital-Skill Complementarity and Inequality: A Macroeconomic Analysis", Federal Reserve of Minneapolis, Stax Report no. 239.

Layard, R., S. Nickell, and R. J ackman (1991), Unemployment. Macroeconomic Performance and the Labour Market, Oxford, Oxford University Press.

Nickell, S. J. (1977), "The Inłuence of Uncertainty on Investment", Economic J ournal, 87, 47-70.

Nickell, S.J . (1997), "Unemployment and Labor Market Rigidities: Europe vs. North America", J ournal of Economic Perspectives, 11 (3), 57-74.

Organisation for Economic Co-operation and Development (1996), International Sectoral Data Base (1960-1995), Statistics Directorate, Paris.

Rotemberg, J. and M. Woodford (1991), "Markups and the Business Cycle", NBER Macroeconomics Annual 1991.

Rotemberg, J . and M. Woodford (1992), "Oligopolistic Pricing and the Exects of A ggregate Demand on Economic Activity", J ournal of Political Economy, 100, 1153-1207.

Rotemberg, J . and M. Woodford (1997), "The Cyclical Behavior of Prices and Costs", mimeo, MIT. Forthcoming in the Handbook of Macroeconomics. 
TABLE 1

The Labor Share and Real Wages in 14 OECD count ries

\begin{tabular}{|c|c|c|c|c|c|}
\hline & \multicolumn{4}{|c|}{$\overline{\text { Labor share }}$} & \multirow{3}{*}{$\begin{array}{c}\begin{array}{c}\text { Real wage } \\
\text { Changes }\end{array} \\
1970-90 \\
\end{array}$} \\
\hline & \multicolumn{3}{|c|}{ Levels } & \multirow{2}{*}{$\begin{array}{c}\text { Changes } \\
1970-90 \\
\end{array}$} & \\
\hline & 1970 & 1980 & 1990 & & \\
\hline United States & 69.7 & 68.3 & 66.5 & -3.3 & 0.4 \\
\hline Canada & 66.9 & 62.0 & 64.9 & -2.0 & 1.3 \\
\hline J apan & 57.5 & 69.1 & 68.0 & 10.5 & 3.5 \\
\hline Germany & 64.1 & 68.7 & 62.1 & -2.0 & 2.0 \\
\hline France & 67.6 & 71.7 & 62.4 & -5.2 & 2.2 \\
\hline Italy & 67.1 & 64.0 & 62.6 & -4.5 & 2.1 \\
\hline United K ingdom & 71.4 & 70.8 & 71.8 & 0.4 & 2.1 \\
\hline Australia & 64.8 & 65.9 & 62.9 & -1.9 & 1.2 \\
\hline Netherlands & 68.0 & 69.5 & 59.2 & -8.8 & 1.8 \\
\hline Belgium & 61.6 & 71.6 & 64.0 & 2.4 & 2.9 \\
\hline Denmark & 68.7 & 71.5 & 63.3 & -5.5 & 1.6 \\
\hline Norway & 68.4 & 66.4 & 63.9 & -4.5 & 2.2 \\
\hline Sweden & 69.7 & 73.6 & 72.6 & 2.9 & 1.6 \\
\hline F inland & 68.6 & 69.6 & 72.3 & 3.7 & 3.5 \\
\hline M ean & 66.7 & 68.8 & 65.5 & -1.3 & 2.0 \\
\hline Standard deviation & 3.5 & 3.1 & 4.0 & 4.7 & 0.8 \\
\hline
\end{tabular}

Not e.- All variables in percentages. The labor share corresponds to the business sector, the real wage is the real compensation per employee in the private sector. Source: OECD Economic Outlook Statistics on M icrocomputer Diskette. 
TABLE 2

Descript ive Stat ist ics of the Main Variabl es

(All observations in the sample; 1973-93)

\begin{tabular}{lrrrr}
\hline \hline & Mean & $\begin{array}{c}\text { Standard } \\
\text { deviation }\end{array}$ & Minimum & Maximum \\
\hline Labor share & 57.2 & 19.7 & 2.4 & 99.0 \\
Capital-output ratio & 3.8 & 4.1 & 0.3 & 49.1 \\
Real price of oil & 31.0 & 16.2 & 5.7 & 96.2 \\
Employment growth rate & -0.5 & 4.4 & -24.1 & 20.5 \\
Output volatility & 2.4 & 2.0 & 0.2 & 43.4 \\
Labor conłict rate & 0.9 & 1.2 & 0.0 & 6.5 \\
\hline
\end{tabular}

Not e.- All variables in percentages, except the capital-output ratio and the real price of oil. The data correspond to an unbalanced panel of 14 industries and 14 countries. Total number of observations: 3022. Source: OECD International Sectoral Data Base (ISDB) (Number of observations by country, year, and industry in Table A 1). 
TABLE 3

Descript ive Stat ist ics of the Labor Share and the Capital-Out put Rat io

By Indust ry and By Count ry (1973-93)

\begin{tabular}{|c|c|c|c|c|c|c|c|}
\hline Industry & $\begin{array}{l}\frac{S_{L}}{1 S D} \\
\text { Sam }\end{array}$ & & Country & $\begin{array}{l}\mathrm{S} \mathrm{L} \\
\mathrm{ISD} \\
\mathrm{Sam}\end{array}$ & & $\begin{array}{c}\mathrm{S}_{\mathrm{L}} \\
\mathrm{Busi} \\
\mathrm{Sec}\end{array}$ & $\begin{array}{l}\mathrm{k} \\
\text { hess } \\
\text { tor }\end{array}$ \\
\hline Agric & 20.5 & 5.7 & U.S & 62.5 & 2.9 & 67.1 & 1.4 \\
\hline Minin & 43.0 & 4.0 & Cana & 57.3 & 3.9 & 63.8 & 1.4 \\
\hline Food & 59.7 & 2.2 & J apan & 51.6 & 2.8 & 68.8 & 2.1 \\
\hline & 74.1 & 2.1 & Ger & 0.6 & 3.1 & 65.8 & 2.7 \\
\hline & .1 & 2.9 & Fra & 8.1 & 2.8 & 67.3 & 2.7 \\
\hline Che & 58.5 & 3.5 & Italy & 49.7 & 3.0 & 64.8 & 2.7 \\
\hline Non & 67.0 & 2.9 & U. Ki & 45.4 & 4.9 & 69.9 & 3.4 \\
\hline Basic & 67.9 & 5.0 & Australia & 48.1 & 4.5 & 65.7 & 3.2 \\
\hline & & 1.7 & & 37.1 & 3.3 & 65.2 & 2.3 \\
\hline $\mathrm{E}$ & 35.7 & 9.7 & $\mathrm{Bel}$ & 58.6 & 2.6 & 67.9 & 2.5 \\
\hline Cons & 67.2 & 0.8 & Den & 61.5 & 4.4 & 66.6 & 4.3 \\
\hline Trade & 64.1 & 1.5 & Norway & 56.9 & 6.4 & 65.9 & 4.0 \\
\hline Trans & 60.3 & 7.3 & Swec & 65.6 & 3.6 & 70.5 & 2.5 \\
\hline Social services & 52.8 & 2.2 & Finland & 57.4 & 5.2 & 72.0 & 3.6 \\
\hline
\end{tabular}

Not e.- $S_{L}$ : Labor share (in percentages), k: Capital-output ratio. Sources: ISDB Sample: OECD International Sectoral Data Base (ISDB) (Number of observations by country, year, and industry in Table $A 1$ ). Business sector: OECD E conomic Outlook Statistics on Microcomputer Diskette. 
TABLE 4

Est imat ion of Labor Share Equation

Dependent variable: In $\mathrm{S}_{\mathrm{L} ; \mathrm{ijt}}$

\begin{tabular}{|c|c|c|c|c|}
\hline & $\begin{array}{c}\text { Capital- } \\
\text { output } \\
\text { ratio } \\
\text { ln } k_{i j t}\end{array}$ & $\overline{\text { t-ratio }}$ & $\begin{array}{l}\begin{array}{l}\text { Real oil } \\
\text { price }\end{array} \\
\ln \left(q_{j t}=p_{j t}\right)\end{array}$ & t-ratio \\
\hline \multicolumn{5}{|l|}{ Industry: } \\
\hline A griculture & -1.40 & $(4.12)$ & 0.29 & (2.12) \\
\hline Mining & -0.07 & (3.48) & -0.19 & (3.16) \\
\hline Food & 0.03 & (4.19) & -0.08 & (2.67) \\
\hline Textiles & 0.05 & $(4.29)$ & -0.02 & (2.26) \\
\hline Paper & 0.21 & (4.54) & -0.06 & (2.36) \\
\hline Chemicals & 0.39 & $(4.06)$ & -0.19 & (2.83) \\
\hline Non-metallic minerals & 0.47 & (4.97) & -0.18 & (3.16) \\
\hline Basic metal & 0.99 & (4.44) & -0.51 & (3.34) \\
\hline Machinery & 0.19 & (4.55) & -0.05 & $(2.41)$ \\
\hline Elec., Gas \& Water & 0.04 & $(4.05)$ & -0.18 & (2.95) \\
\hline Construction & 0.14 & (3.99) & -0.02 & (2.17) \\
\hline Trade & 0.46 & $(4.80)$ & -0.08 & $(2.53)$ \\
\hline Transport \& Communic. & -0.09 & (3.87) & -0.02 & (2.16) \\
\hline Social services & 0.05 & $(4.09)$ & -0.08 & (2.58) \\
\hline J oint signi...cance $(p)$ : & 40.88 & $(0.00)$ & 61.79 & $(0.00)$ \\
\hline Constant & -0.29 & (2.36) & & \\
\hline Employment change $\left(\$ \ln n_{i j t}\right)$ & -0.57 & (4.08) & & \\
\hline Output volatility $\left({ }_{4 j \mathrm{t}}\right)$ & -0.47 & $(3.80)$ & & \\
\hline Labor confict rate $\left({ }^{f} \mathrm{f}_{\mathrm{j}} \mathrm{t}\right)$ & -2.29 & (2.79) & & \\
\hline Sargan: $p$-value and d.f. & 0.10 & (61) & & \\
\hline Dix. Sargan: $p$-value and d.f. & 0.09 & (45) & & \\
\hline$m_{2}$ & -1.23 & & & \\
\hline
\end{tabular}

Not e.- No. of observations: 3022, no. of industry-country units: 165, Period: 1973-93. Method: Instrumental variables, system estimator. T wo-step estimates of coec cients and t-ratios (in parenthesis) robust to residual heteroskedasticity and autocorrelation. Diagnostic statistics: $p$-value of the Sargan test (with degrees of freedom beside), $p$-value of the Dixerence Sargan test (with d.f. beside), and coet cient of second-order correlation of the residuals. Except for the ..rst one, $\mathrm{t}$-ratios on In $\mathrm{k}_{\mathrm{ijt}}$ and $\ln \left(\mathrm{q}_{\mathrm{t}}=\mathrm{p}_{\mathrm{j} t}\right)$ refer to signi..cance vis-à-vis A griculture. $\mathrm{p}$ - 
values of Wald test statistics of joint signi..cance of all In $k_{i j t}$ and $\ln \left(q_{i t}=p_{j t}\right)$ terms reported next to them. Instruments. (a) Dixerences: $d_{i} \ln K_{i j ; t_{i} 2},\left(\ln K_{i j ; t_{i}}\right)^{2}$,

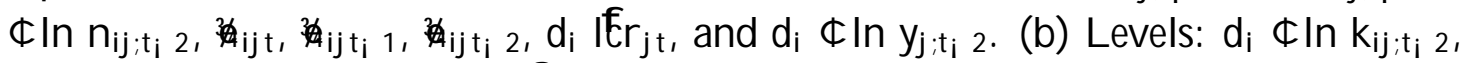

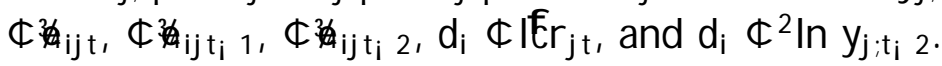


TABLE 5

Variant $s$ of the Labor Shar e Equation

Dependent variable: In $\mathrm{S}_{\mathrm{L} ; \mathrm{ijt}}$

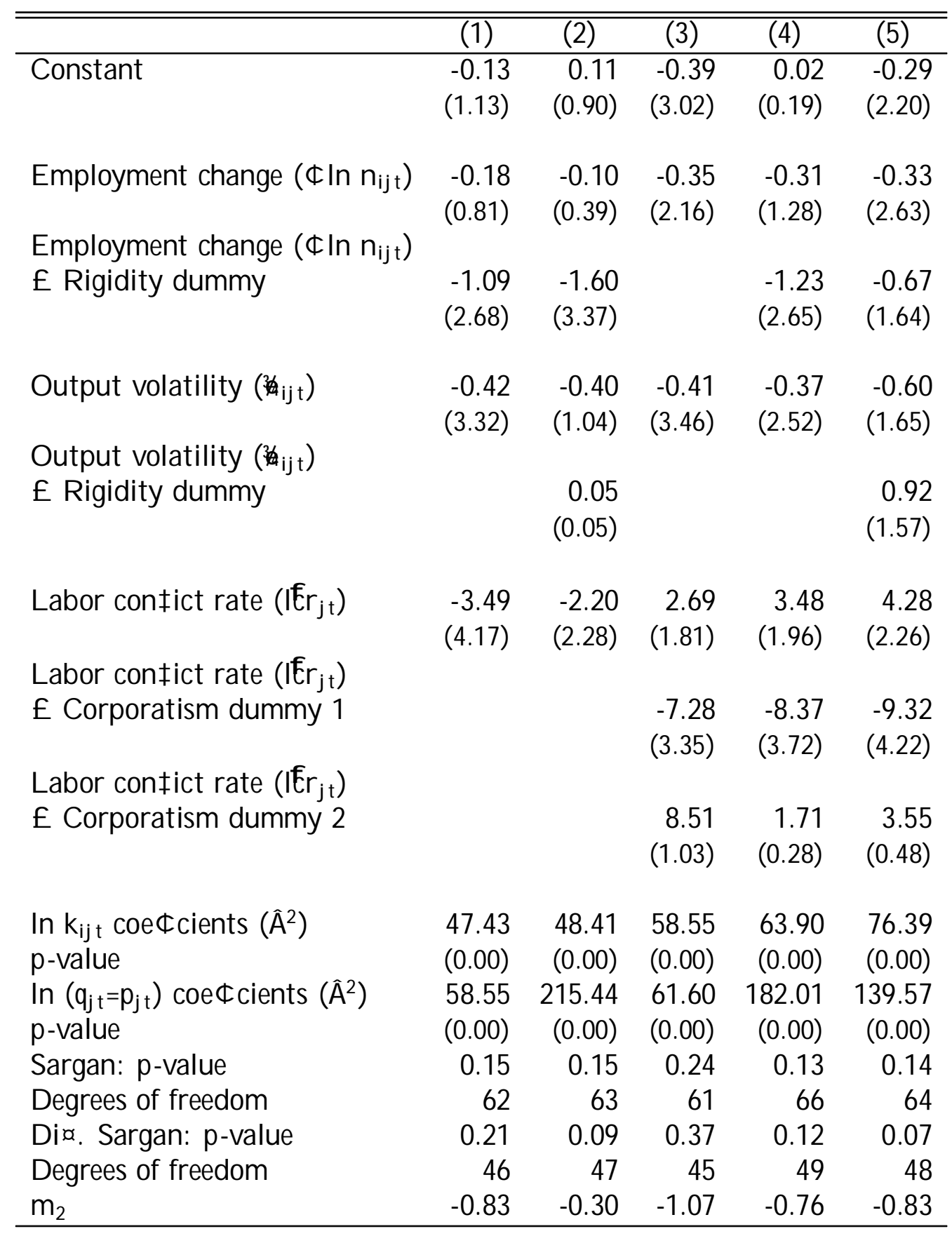

Not e.- Estimation as in Table 4. A dded instruments: the dummy variables (rigid, cor p1, and cor p2) whenever they appear interacted with any of the regressors. 
Figure 1. The I abor share in the UK

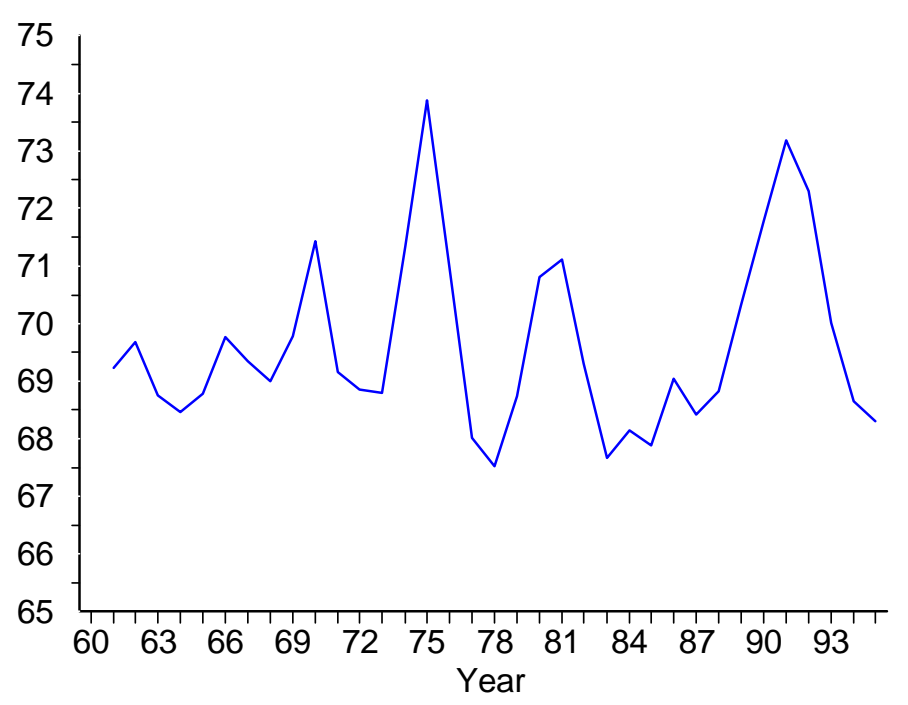

Figure 2. The I abor share in the US

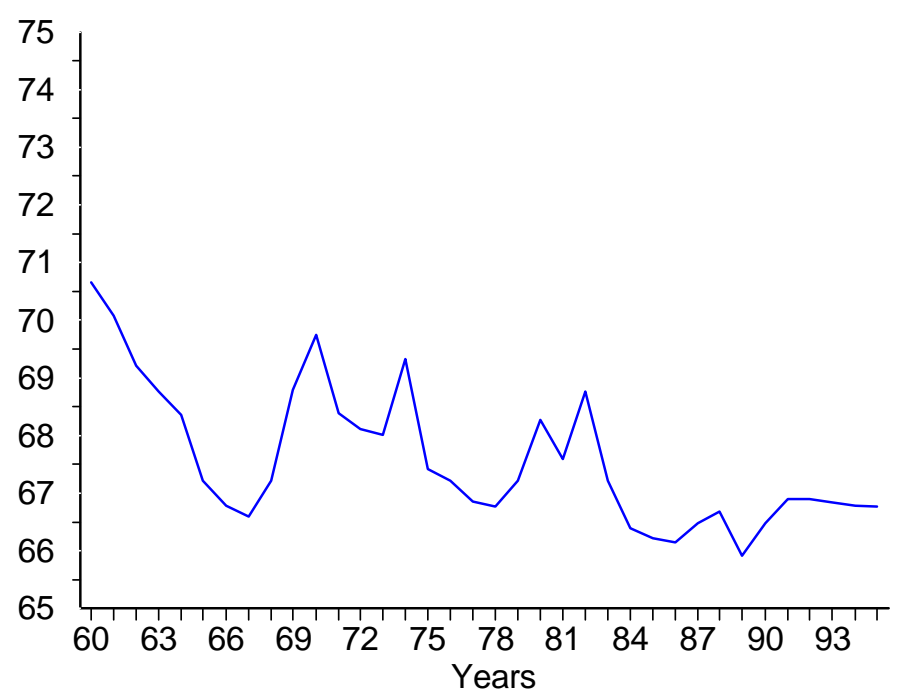


Figure 3. The I abor share in J apan

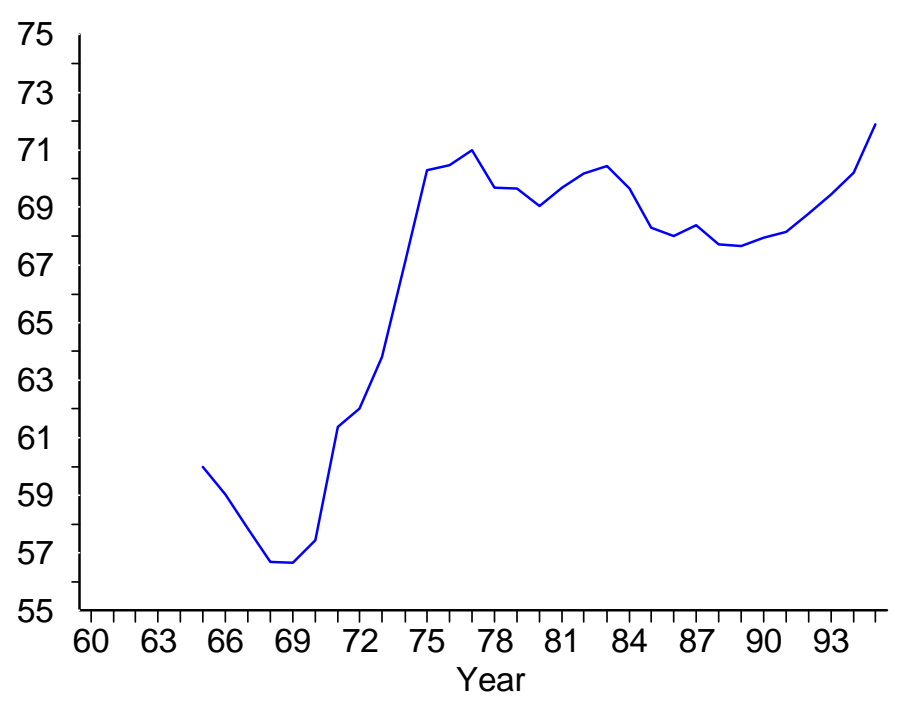

Figure 4. The I abor share in France and Ger many

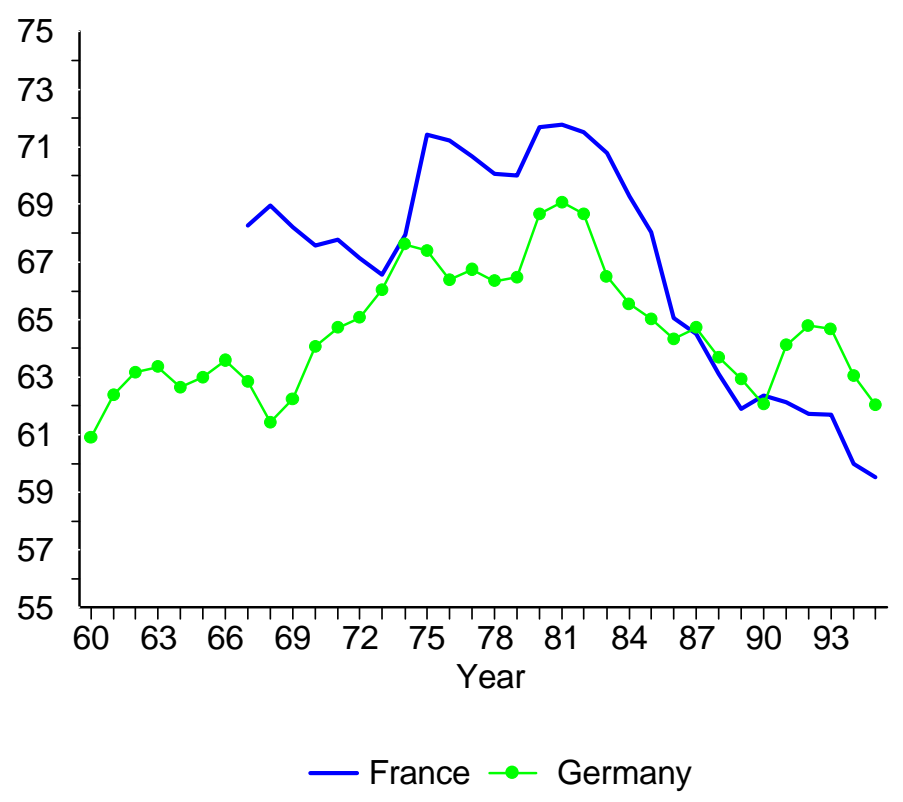


Figure 5. The Share-Capital (SK) Curve

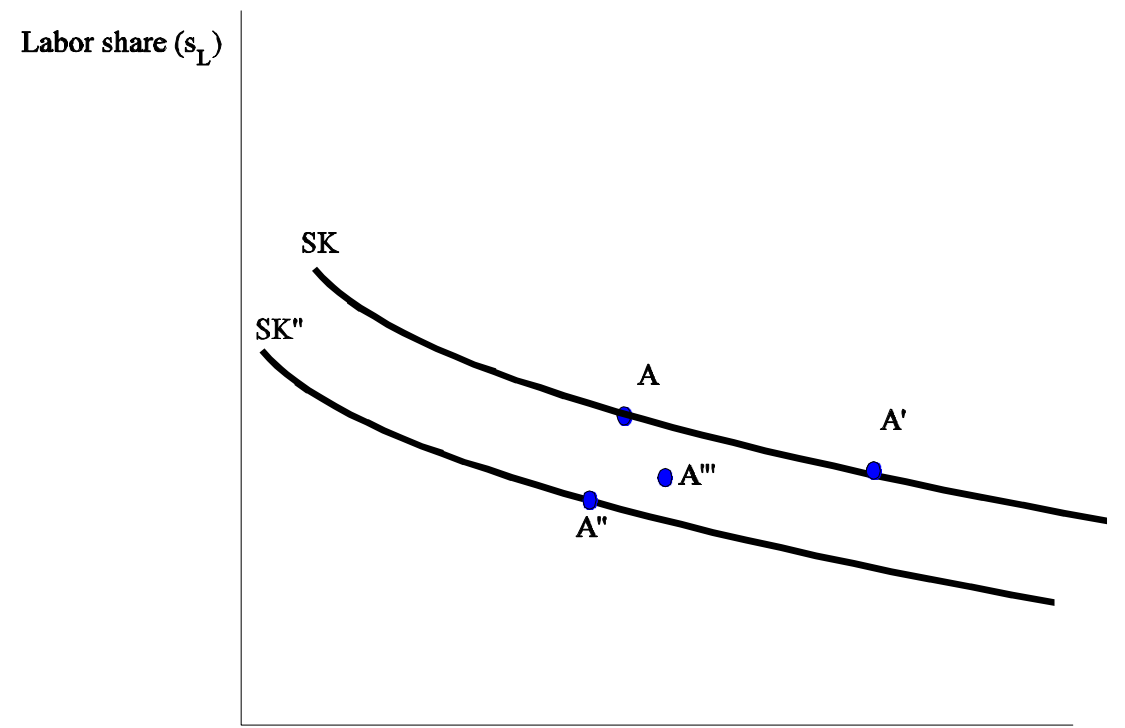

A: Initial position of the economy

Capital-output ratio $(k)$

$A^{\prime}$ : Increase in wages

$A^{\prime \prime}$ : Change in the price of oil

$A^{\prime \prime \prime}$ : Increase in the markup 


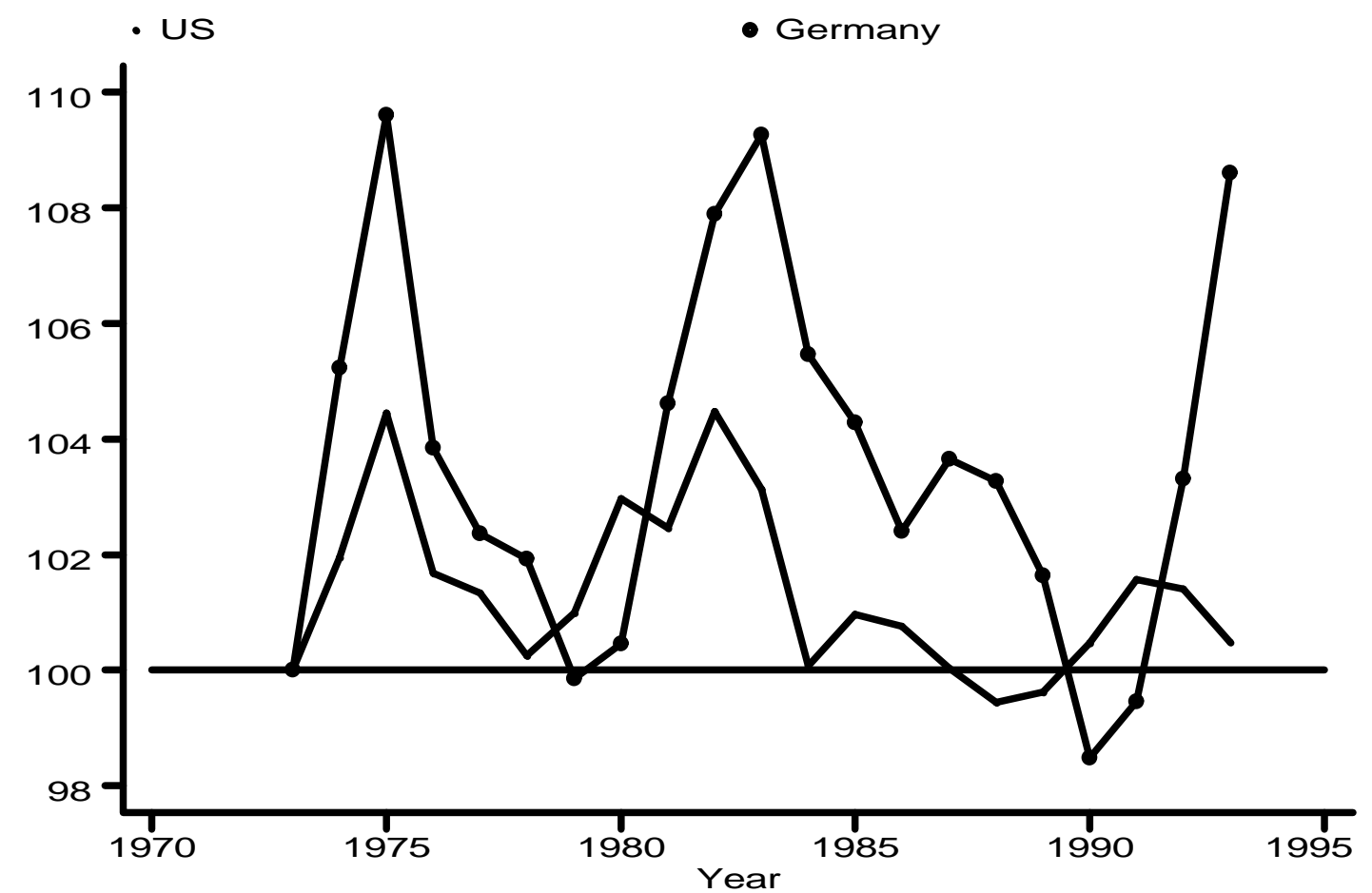

Figure 6. Wage gaps. US and Germany. 


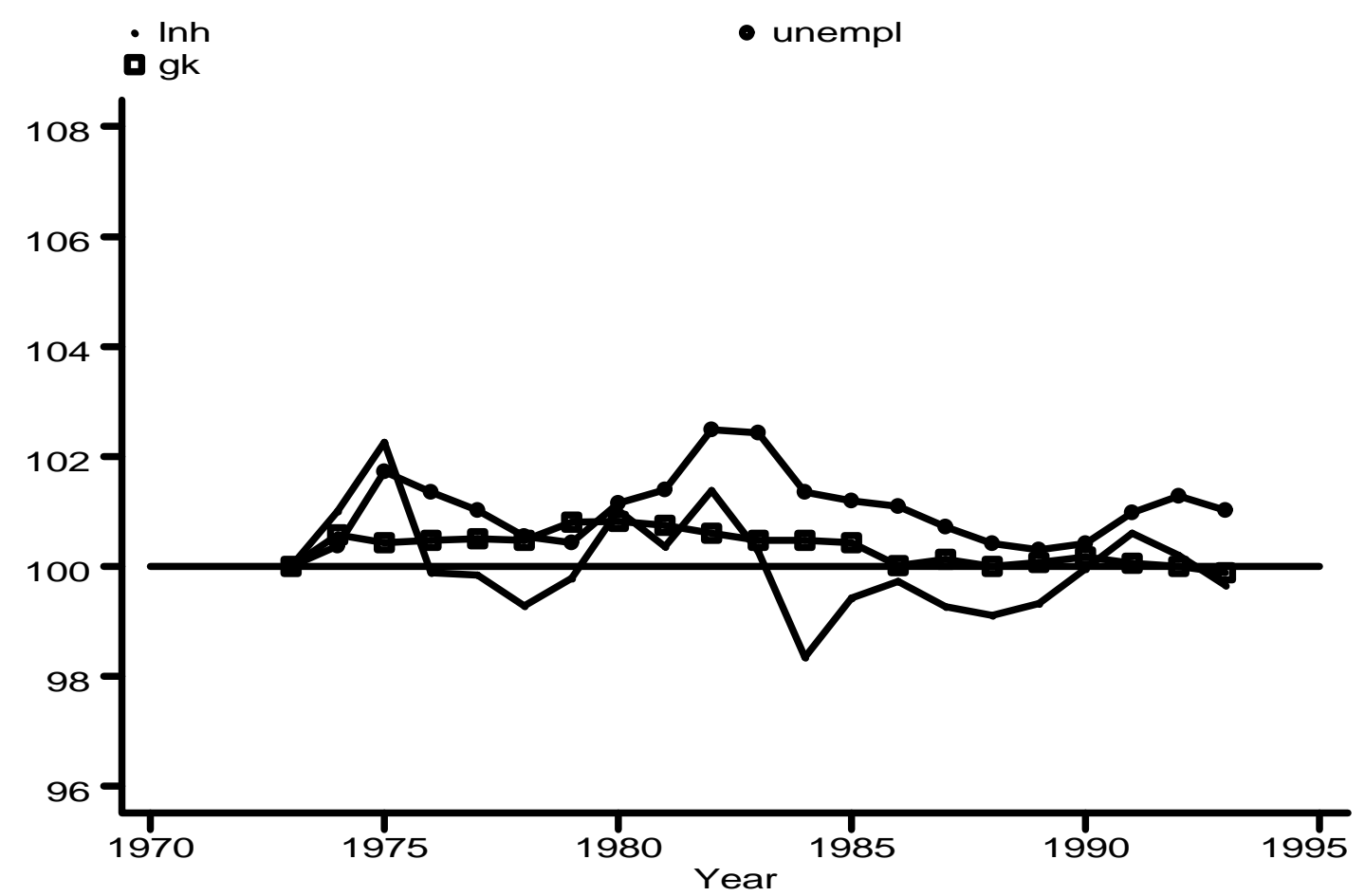

Figure 7a. Wage gap decomposition, US. 


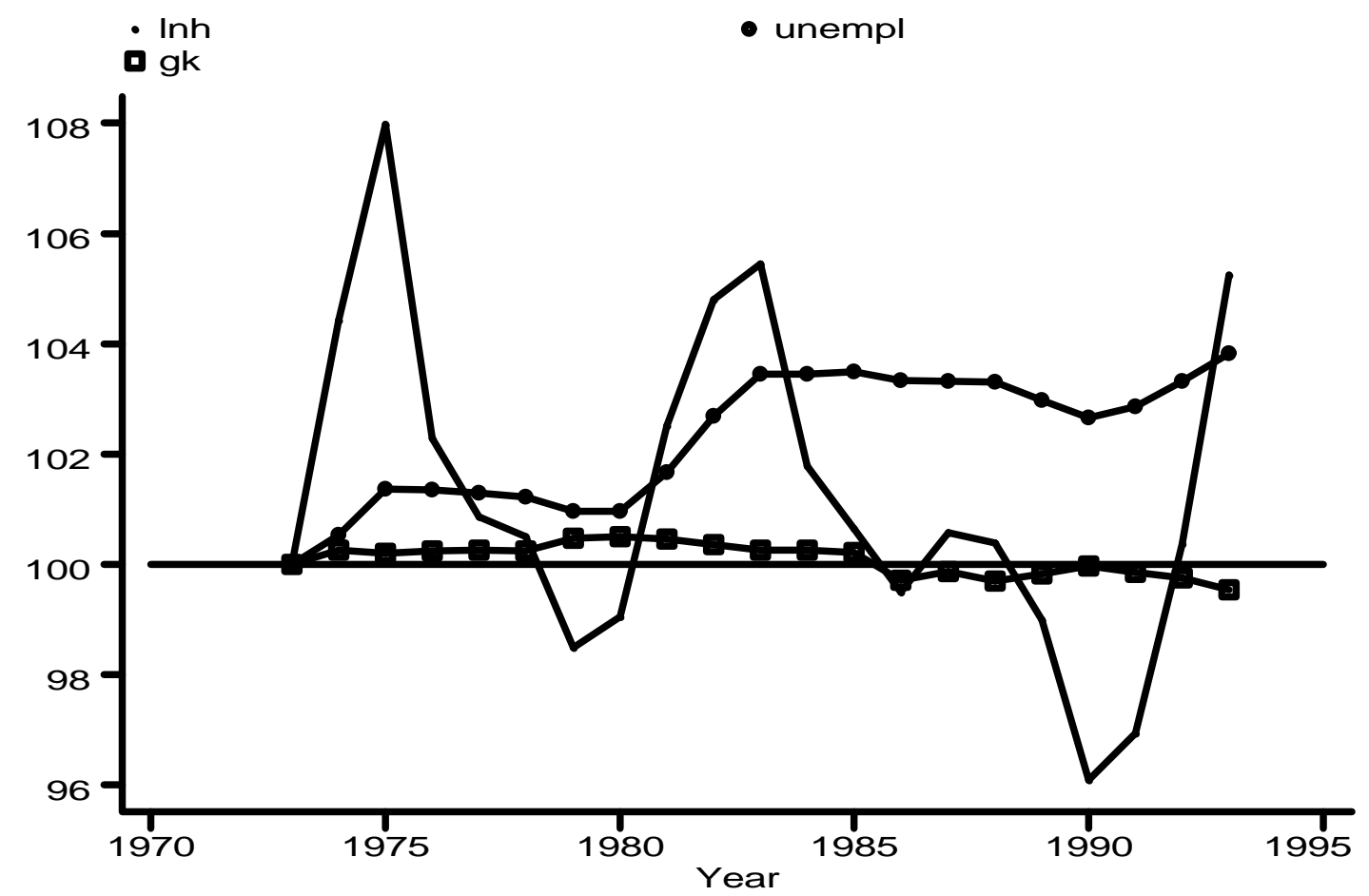

Figure 7b. Wage gap decomposition, Germany. 


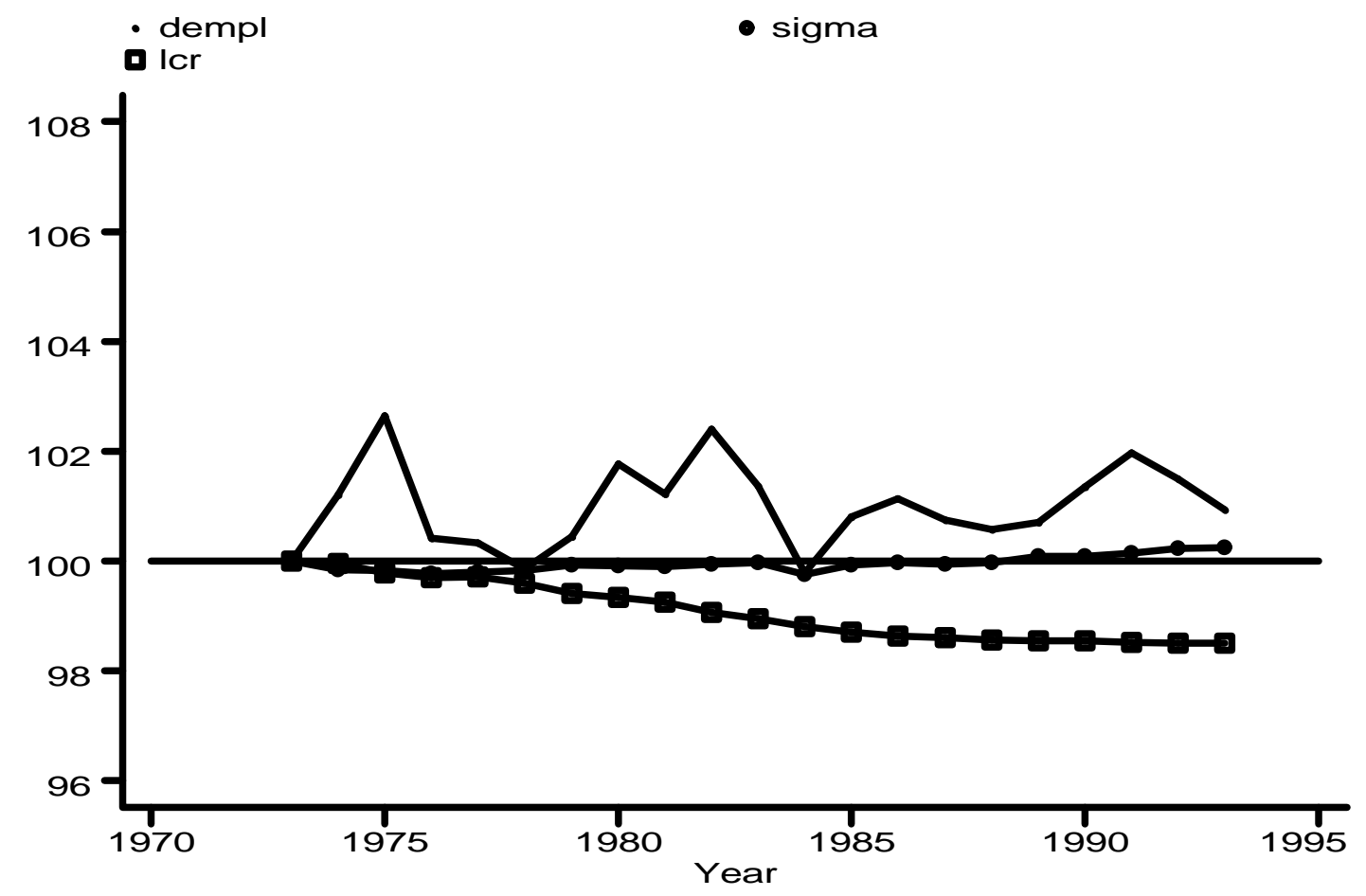

Figure 8a. Labor demand shifts decomposition, US. 


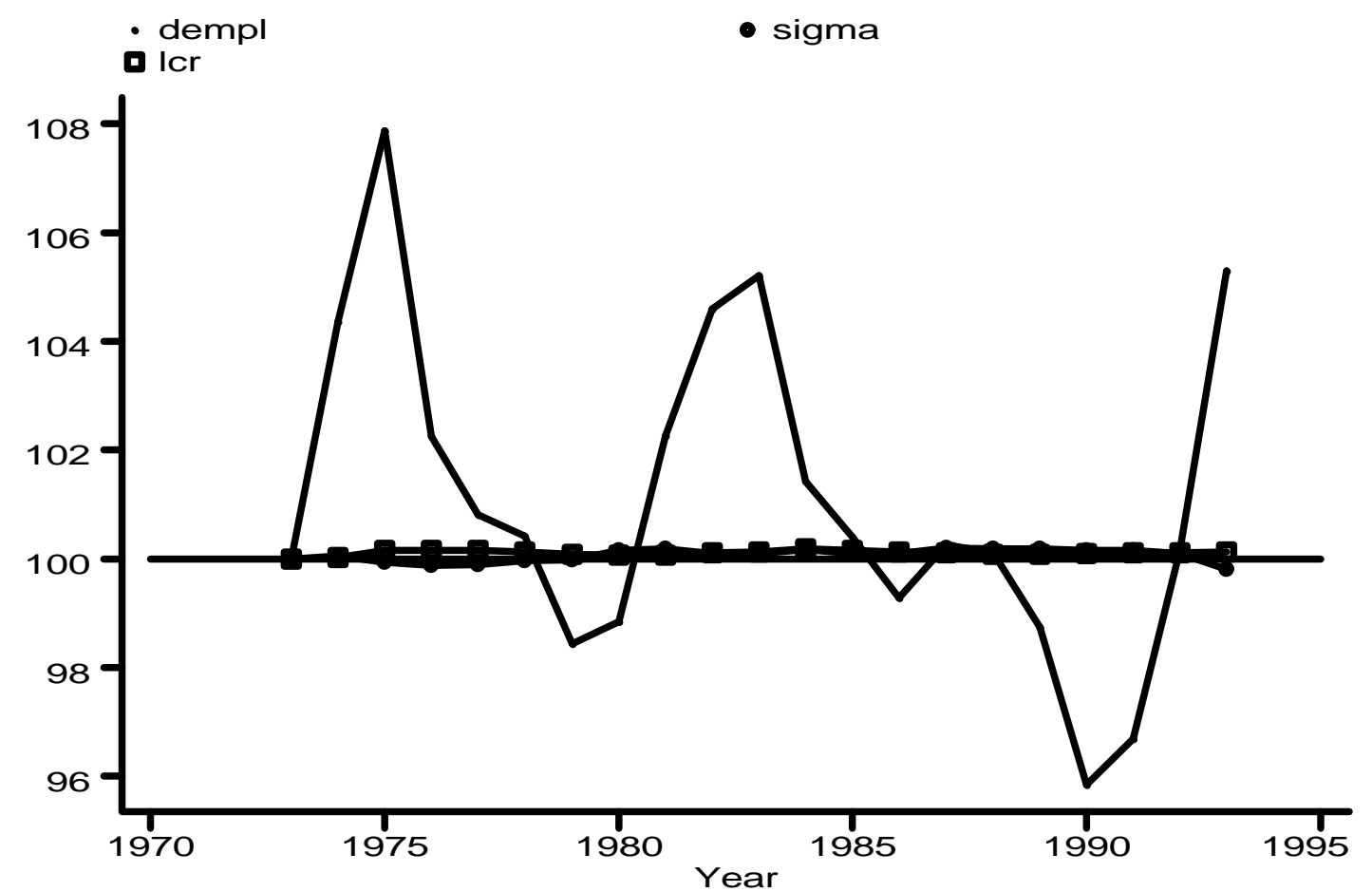

Figure 8b. Labor demand wage gap decomposition - Germany 